\title{
Sensitivity of the Community Multiscale Air Quality (CMAQ) model v4.7 results for the eastern United States to MM5 and WRF meteorological drivers
}

\author{
K. W. Appel, S. J. Roselle, R. C. Gilliam, and J. E. Pleim \\ Atmospheric Modeling and Analysis Division, National Exposure Research, Laboratory, Office of Research and \\ Development, US Environmental Protection Agency, RTP, NC 27711, USA
}

Received: 7 July 2009 - Published in Geosci. Model Dev. Discuss.: 30 July 2009

Revised: 26 January 2010 - Accepted: 15 February 2010 - Published: 23 February 2010

\begin{abstract}
This paper presents a comparison of the operational performances of two Community Multiscale Air Quality (CMAQ) model v4.7 simulations that utilize input data from the 5th-generation Mesoscale Model (MM5) and the Weather Research and Forecasting (WRF) meteorological models. Two sets of CMAQ model simulations were performed for January and August 2006. One set utilized MM5 meteorology (MM5-CMAQ) and the other utilized WRF meteorology (WRF-CMAQ), while all other model inputs and options were kept the same. For January, predicted ozone $\left(\mathrm{O}_{3}\right)$ mixing ratios were higher in the Southeast and lower Mid-west regions in the WRF-CMAQ simulation, resulting in slightly higher bias and error as compared to the MM5CMAQ simulations. The higher predicted $\mathrm{O}_{3}$ mixing ratios are attributed to less dry deposition of $\mathrm{O}_{3}$ in the WRF-CMAQ simulation due to differences in the calculation of the vegetation fraction between the MM5 and WRF models. The WRF-CMAQ results showed better performance for particulate sulfate $\left(\mathrm{SO}_{4}^{2-}\right)$, similar performance for nitrate $\left(\mathrm{NO}_{3}^{-}\right)$, and slightly worse performance for nitric acid $\left(\mathrm{HNO}_{3}\right)$, total carbon (TC) and total fine particulate $\left(\mathrm{PM}_{2.5}\right)$ mass than the corresponding MM5-CMAQ results. For August, predictions of $\mathrm{O}_{3}$ were notably higher in the WRF-CMAQ simulation, particularly in the southern United States, resulting in increased model bias. Concentrations of predicted particulate $\mathrm{SO}_{4}^{2-}$ were lower in the region surrounding the Ohio Valley and higher along the Gulf of Mexico in the WRF-CMAQ simulation, contributing to poorer model performance. The primary causes of the differences in the MM5-CMAQ and WRF-CMAQ simulations appear to be due to differences
\end{abstract}

Correspondence to: K. W. Appel (appel.wyat@epa.gov) in the calculation of wind speed, planetary boundary layer height, cloud cover and the friction velocity $\left(u_{*}\right)$ in the MM5 and WRF model simulations, while differences in the calculation of vegetation fraction and several other parameters result in smaller differences in the predicted CMAQ model concentrations. The performance for $\mathrm{SO}_{4}^{2-}, \mathrm{NO}_{3}^{-}$and $\mathrm{NH}_{4}^{+}$ wet deposition was similar for both simulations for January and August.

\section{Introduction}

Air quality models, such as the Community Multiscale Air Quality (CMAQ) modeling system (Byun and Schere, 2006) and the Comprehensive Air Quality Model with extensions (CAMx) (ENVIRON, 2009), require gridded, high resolution (both temporally and spatially) meteorological data in order to accurately predict the transformation, transport and fate of pollutants in the atmosphere. Gridded Eulerian meteorological models, such as the 5th Generation Mesoscale Model (MM5; Grell et al., 1994) and the Weather Research and Forecasting model (WRF; Skamarock et al., 2008), are used to provide the meteorological data required by air quality models.

For the past 15 years, MM5 has been used to provide meteorological data for air quality simulations. The modular design of MM5 allows users to choose among various physics options such as: land-surface models (LSM), planetary boundary layer (PBL), radiation, microphysics and cloud schemes in order to optimize the model for a specific application. However, releases of new versions of MM5 by the community have ceased since the WRF model has taken its place. The WRF model incorporates the same capabilities

Published by Copernicus Publications on behalf of the European Geosciences Union. 
Table 1. Options used for the MM5 and WRF model simulations.

\begin{tabular}{ccc}
\hline Model & MM5 & WRF \\
\hline Version & v3.7.4 & ARW core v3.0 \\
Grid spacing & $12 \mathrm{~km} \times 12 \mathrm{~km}$ & $12 \mathrm{~km} \times 12 \mathrm{~km}$ \\
PBL model & ACM2 & ACM2 \\
LSM & Pleim-Xiu & Pleim-Xiu \\
Sub-grid convection scheme & Kain-Fritsch 2 & Kain-Fritsch 2 \\
Shortwave radiation scheme & Dudhia & Dudhia \\
Longwave radiation scheme & RRTM & RRTM \\
Explicit microphysics scheme & Reisner 2 & Thompson \\
Objective analysis approach & Rawins & OBSGRD \\
\hline
\end{tabular}

as the MM5 model, but includes various improvements in the underlying dynamics of the model (e.g. mass conservation) along with updated physics, including new versions of the LSM, PBL, radiation and cloud microphysics schemes (add reference).

Although the WRF model has been available for several years and is being used operationally by the National Centers for Environmental Prediction (NCEP) and many other research groups, the model has seen limited use for retrospective air quality modeling applications. Until recently, operational performance of retrospective WRF model simulations has lagged that of MM5 simulations, due mostly to a lack of a comparable analysis nudging scheme. Analysis nudging is widely used by the air quality community to improve the performance of the meteorological simulations used in retrospective air quality simulations. A recently released version of an objective analysis utility for WRF (Obsgrid; Deng et al., 2008) improves the operational performance of retrospective WRF model simulations, making the performance comparable to MM5 (Gilliam and Pleim, 2010).

While other studies have compared the performance of air quality model predictions using different meteorological models (e.g. Smyth et al., 2006; de Meij et al., 2009), no studies have specifically compared the performance of MM5 and WRF driven CMAQ model simulations. This study has two main objectives. One is to test the WRF-CMAQ modeling system to insure that no major model performance issues exist (e.g. issues that would prohibit using the WRF model with the CMAQ model), as using WRF model data to drive the CMAQ model is a relatively new option and performance issues may exist. The second objective is to inform the CMAQ model user and development communities of the differences in CMAQ model performance they might encounter when transitioning from MM5 to the WRF model as the meteorological driver for CMAQ. This study specifically examines the operational performance of two sets of January and August 2006 CMAQ simulations, with one set using meteorological data provided by MM5 (MM5-CMAQ) and the other using data provided by the WRF model (WRF-
CMAQ). The configurations of the meteorological models used are typical of those that would be used for regulatory air quality simulations and no modifications have been made to the underlying codes of either models to make them more consistent with each other (e.g. "out-of-the-box" configurations are used). The performance results for each simulation are presented and where possible the likely reasons for large differences in performance are discussed.

\section{Methodology}

\subsection{MM5 and WRF model simulations}

MM5 and WRF model simulations were performed for the eastern United States for January and August 2006 (with a 10 day spin-up period in the previous month) that utilize a horizontal grid with $12-\mathrm{km}$ by $12-\mathrm{km}$ grid cells and 34 vertical layers extending up to $100 \mathrm{hPa}$. Boundary conditions for both the MM5 and WRF simulations were provided directly by the 12-km North American Model (NAM) simulation for the same time period. The details provided here regarding the MM5 and WRF model simulations are based on Gilliam and Pleim (2010), which compares the performance of similarly configured MM5 and WRF simulations as used in this study.

The MM5 simulation utilized version 3.7.4 of the model, with the Asymmetric Convective Model 2 (ACM2; Pleim, 2007a, b) PBL model, Pleim-Xiu (PX; Xiu and Pleim, 2001; Pleim and Xiu, 1995) LSM, Dudhia shortwave radiation scheme (Dudhia, 1989), RRTM longwave radiation scheme (Mlawer et al., 1997), Kain-Fritsch 2 (KF2; Kain, 2004) subgrid convective scheme and the Reisner-2 (Reisner et al., 1998) explicit microphysics scheme. The PX LSM included indirect soil moisture and temperature nudging (Pleim and Xiu, 2003; Gilliam and Pleim, 2010). The similarly configured WRF model simulation utilized the Advanced Research WRF (ARW) core version 3.0 (Skamarock et al., 2008), with the ACM2 PBL model, PX LSM, Dudhia shortwave and RRTM longwave radiation schemes, KF2 sub-grid convective scheme and the Thompson (Thompson et al., 2004) microphysics scheme. A summary of the configuration options for the MM5 and WRF model simulations is shown in Table 1 . These options were chosen in order to obtain consistent performance for the two simulations, and are those options typically used by the MM5 and WRF communities, especially for retrospective air quality simulations.

Several distinct nudging strategies are used in both the MM5 and WRF simulations that employ the PX LSM. These include four-dimensional data assimilation (FDDA) and indirect soil moisture and temperature $(T)$ nudging. In both the MM5 and WRF model simulations, FDDA is essentially the same in terms of the analyses used and the nudging configuration, which follow after Stauffer et al. (1991) and Otte (2008a) and are described in detail for these particular 
simulations by Gilliam and Pleim (2010). The reanalysis fields considered are the wind components in the east-west and north-south directions, $T$ and water vapor mixing ratio $(w)$. The winds are nudged at all model levels, while $T$ and $w$ are only nudged above the model simulated PBL in the WRF and MM5 simulations. Indirect soil moisture and soil $T$ nudging were used by both the MM5 and WRF models. It should be noted that for the MM5 simulation the RAWINS tool was used to create the 2-meter $(\mathrm{m}) T$ and 2-m $w$ analyses, while for the WRF simulation the Obsgrid tool, a relative of RAWINS, was used. Gilliam and Pleim (2010) demonstrated that while these tools are very similar and ingest the same base analysis and surface observations, Obsgrid produces a reanalysis with an overall better comparison to the surface observations.

\subsection{CMAQ model simulations}

The CMAQ model simulations were performed using CMAQv4.7 (Foley et al., 2009) for the eastern United States for January and August 2006 using a three day spin-up period in the previous month on the same grid as the meteorology models except that its horizontal dimensions were reduced by 5 grid cells on each of the 4 lateral boundaries to avoid spurious boundary artifacts in the meteorology simulations. CMAQ was configured using the AERO5 aerosol module and the CB05 chemical mechanism with chlorine chemistry extensions (Yarwood et al., 2005) and the ACM2 PBL scheme. The vertical layers for the CMAQ simulations match those of the meteorological simulations. Version 3.4.1 of the Meteorology-Chemistry Interface Processor (MCIP; Otte et al., 2005) was used to process the MM5 and WRF meteorology for use with CMAQ. The simulations used a 2005 base year emissions inventory which was updated with year specific mobile emissions and Continuous Emissions Monitoring System (CEMS) data for point emissions for 2006. The latest version of the CMAQ model includes the option to calculate biogenic and plume rise emissions in-line during the simulation, an option that was used for this study.

\subsection{Model assessment techniques}

The evaluation of the MM5, WRF and CMAQ model simulations was done primarily using the Atmospheric Model Evaluation Tool (AMET) (Appel and Gilliam, 2008). Meteorological predictions of 2-m $T, 2-\mathrm{m} w$ and 10-m wind speed (WS) are paired in space and time with observations from the Meteorological Assimilation Data Ingest System (MADIS; http://madis.noaa.gov) database. The performance of the predictions is then assessed using available analyses in the AMET. Additionally, predicted monthly precipitation is compared against observations from the National Precipitation Analysis (NPA), which is a blend of radar estimated precipitation and rain gauge data (Fulton, 1998; Seo, 1998a, b).
The CMAQ model predictions are paired in space and time with observations from the Environmental Protections Agency's (EPA) Air Quality System (AQS) for $\mathrm{O}_{3}$, the Interagency Monitoring of PROtected Visual Environments (IMPROVE) network, the Chemical Speciation Network (CSN; previously called the Speciation Trends Network(STN)) and the Clean Air Status and Trends Network (CASTNet) for fine particulate matter, and the National Atmospheric Deposition Program (NADP) network for wet deposition species. Observations from the AQS (353 sites in January; 861 sites in August) are hourly; observations from the IMPROVE network (90 sites) and the CSN (174 sites in January; 157 sites in August) are daily average concentrations available every third day; CASTNet (67 sites) observations are weekly average concentrations, while the NADP network (202 sites) observations are weekly accumulated values.

Several statistical quantities are provided that assess the model bias and error. Root Mean Square Error (RMSE), Normalized Mean Error (NME), Normalized Median Error (NMdnE), Mean Error (ME) and Median Error (MdnE) are used to assess model error. Normalized Mean Bias (NMB), Normalized Median Bias (NMdnB), Mean Bias (MB) and Median Bias (MdnB) are used to assess model bias. The MdnB, MdnE, NMdnB and NMdnE are defined below as:

$\operatorname{MdnB}=\operatorname{median}\left(C_{\mathrm{M}}-C_{\mathrm{O}}\right)_{\mathrm{N}}$

$\operatorname{MdnE}=\operatorname{median}\left|C_{\mathrm{M}}-C_{\mathrm{O}}\right|_{\mathrm{N}}$

$\mathrm{NMdnB}=\frac{\operatorname{median}\left(C_{\mathrm{M}}-C_{\mathrm{O}}\right)_{\mathrm{N}}}{\operatorname{median}\left(C_{\mathrm{O}}\right)_{\mathrm{N}}} \cdot 100 \%$

$\mathrm{NMdnE}=\frac{\operatorname{median}\left|C_{\mathrm{M}}-C_{\mathrm{O}}\right|_{\mathrm{N}}}{\operatorname{median}\left(C_{\mathrm{O}}\right)_{\mathrm{N}}} \cdot 100 \%$

where $C_{\mathrm{M}}$ and $C_{\mathrm{O}}$ are modeled and observed concentrations, respectively, and $\mathrm{N}$ is the total number of model/observation pairs. In Eqs. (2) and (4) which calculate error, the absolute value of the difference between the modeled and observed concentration is used, denoted in the equations by the vertical bars. Median is preferred here over mean since median gives a better representation of the central tendency of the data than the mean when analyzing data with non-normal distributions, which the observed PM species data often are. The metrics are normalized by the median of observed data to avoid instances of extremely large biases and errors that can occur when normalizing by the individual observations for observed concentrations that are very low, which is possible with the species being examined here. Additional details regarding these statistics and how the observations from the various observing networks are paired with CMAQ predictions and are used in the AMET can be found in Appel et al. (2007, 2008). 


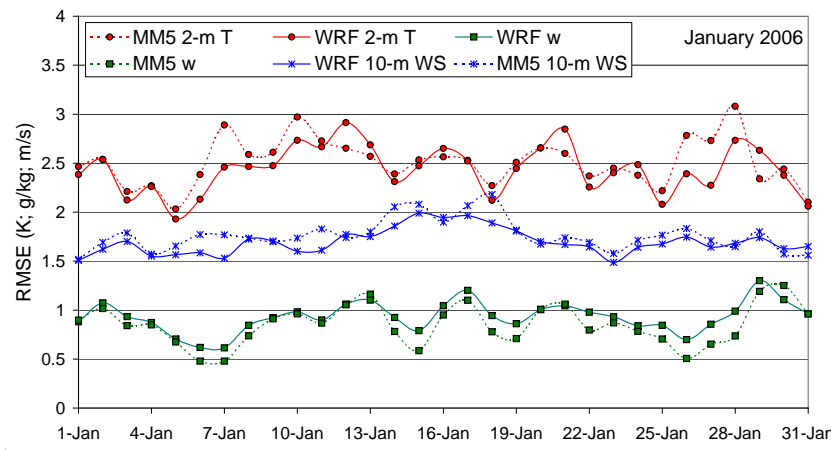

(a)

Day of Month
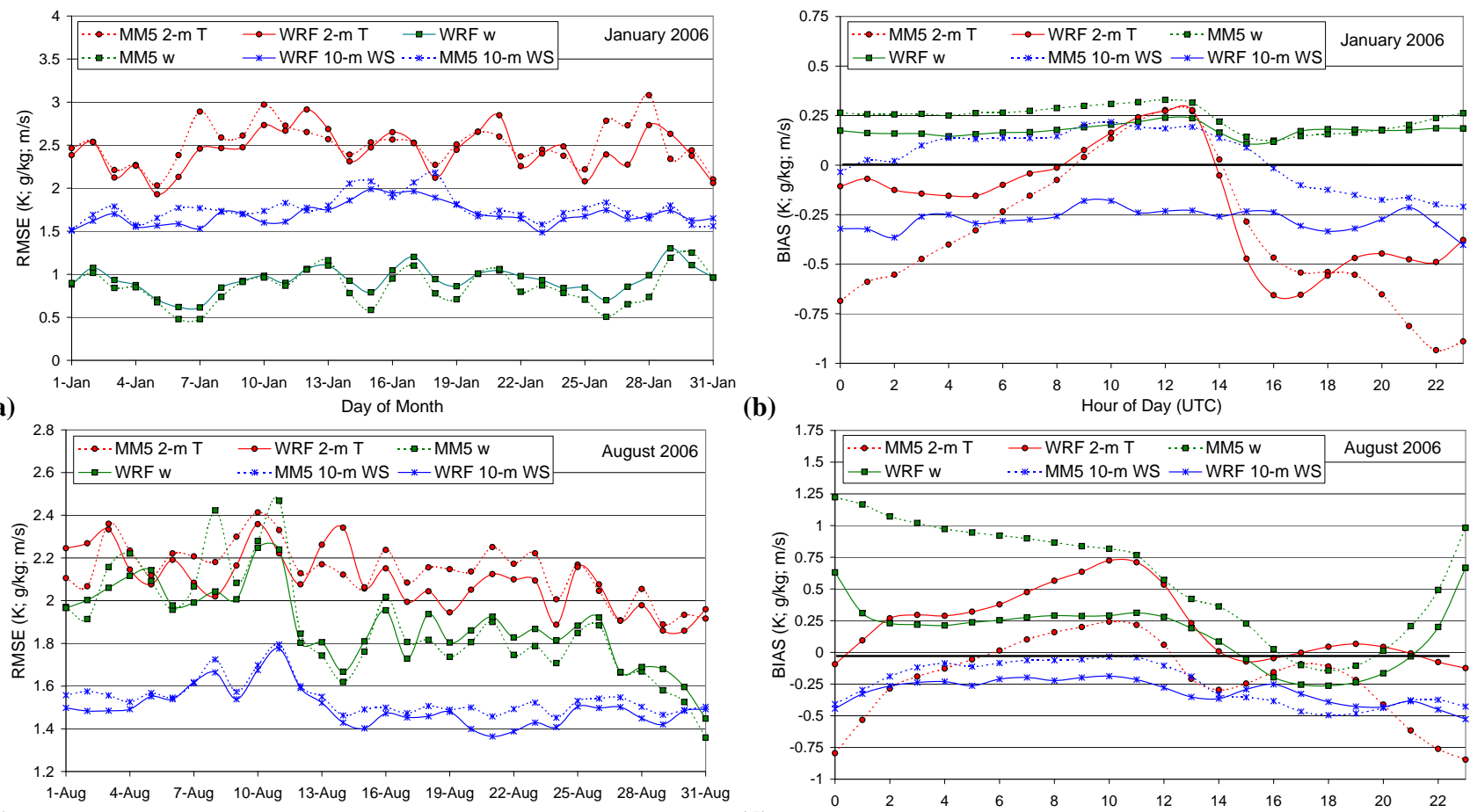

(b)

(c)

$$
\text { Day of Month }
$$

(d)

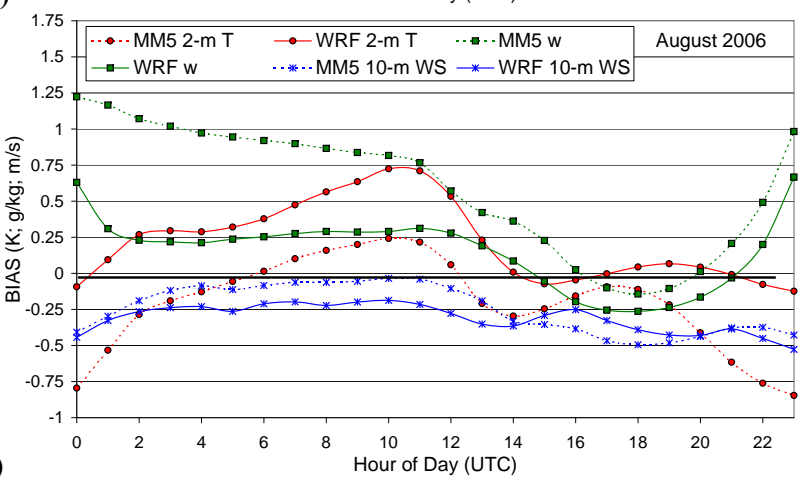

Fig. 1. (a) Daily RMSE and (b) hourly bias of 2-m $T$ (red; K), $w$ (green; $\mathrm{g} \mathrm{kg}^{-1}$ ) and 10-m WS (blue; $\mathrm{m} \mathrm{s}^{-1}$ ) for the MM5 (dashed) and WRF (solid) model simulations for January 2006. (c) As in (a), except for August 2006. (d) As in (b), except for August 2006.

\section{MM5 and WRF model performance assessment}

Since the objective of this study is to examine the differences between the MM5-CMAQ and WRF-CMAQ predictions, it is important to determine what, if any, significant differences exist between the MM5 and WRF model simulations from an operational performance perspective. This section provides limited comparison of the MM5 and WRF model performance, since a more detailed assessment of the MM5 and WRF model performance can be found in Gilliam and Pleim (2010).

\subsection{January}

Figure 1a presents a comparison of the daily RMSE for 2-m $T, 2-\mathrm{m} w$ and 10-m WS for January for the MM5 and WRF model simulations. The RMSE for all three variables is very similar for January, although there are some periods where the RMSE for 2-m $T$ is notably higher for the MM5 simulation. Figure $1 \mathrm{~b}$ presents a comparison of the diurnal (hourly) bias for the same three variables for January. The WRF model simulation has much lower bias for 2-m $T$ during the nighttime hours (8 p.m.-8 a.m. EST; 01:00-13:00 UTC) than the MM5 simulation, while the daytime (8 a.m.-8 p.m. EST; 13:00-01:00 UTC) bias is similar for the two simulations. The $\mathrm{w}$ bias is slightly lower in the WRF model simulation throughout most of the day, while the bias in 10-m WS is generally lower in the MM5 simulation. These analyses suggest that the WRF model is generally performing as well as the MM5 for these key meteorological variables for January.

A comparison of the observed accumulated monthly precipitation versus MM5 and WRF predicted precipitation for January is provided in Fig. 2a-c. The spatial pattern and amount of predicted precipitation from the MM5 (Fig. 2b) and WRF (Fig. 2c) model simulations are similar over land, and are generally comparable to the observed precipitation (Fig. 2a). The largest difference in predicted precipitation between the two simulations occurs over the Gulf of Mexico and off the east coast of the United States, where the WRF model predicts much greater precipitation than MM5. It is not possible to determine which model is more correct, since the radar-based precipitation dataset is not available beyond the coast. However, the impact from the differences in the offshore precipitation on CMAQ predictions should be relatively small.

\subsection{August}

Figure 1c shows a comparison of the daily RMSE for 2-m $T$, $w$ and 10-m WS for August for the MM5 and WRF simulations. The RMSE values for all three variables track very close to each other for most of the month. The RMSE for $w$ is higher in both simulations for the first third of the month as compared to the other two-thirds due to the higher moisture 

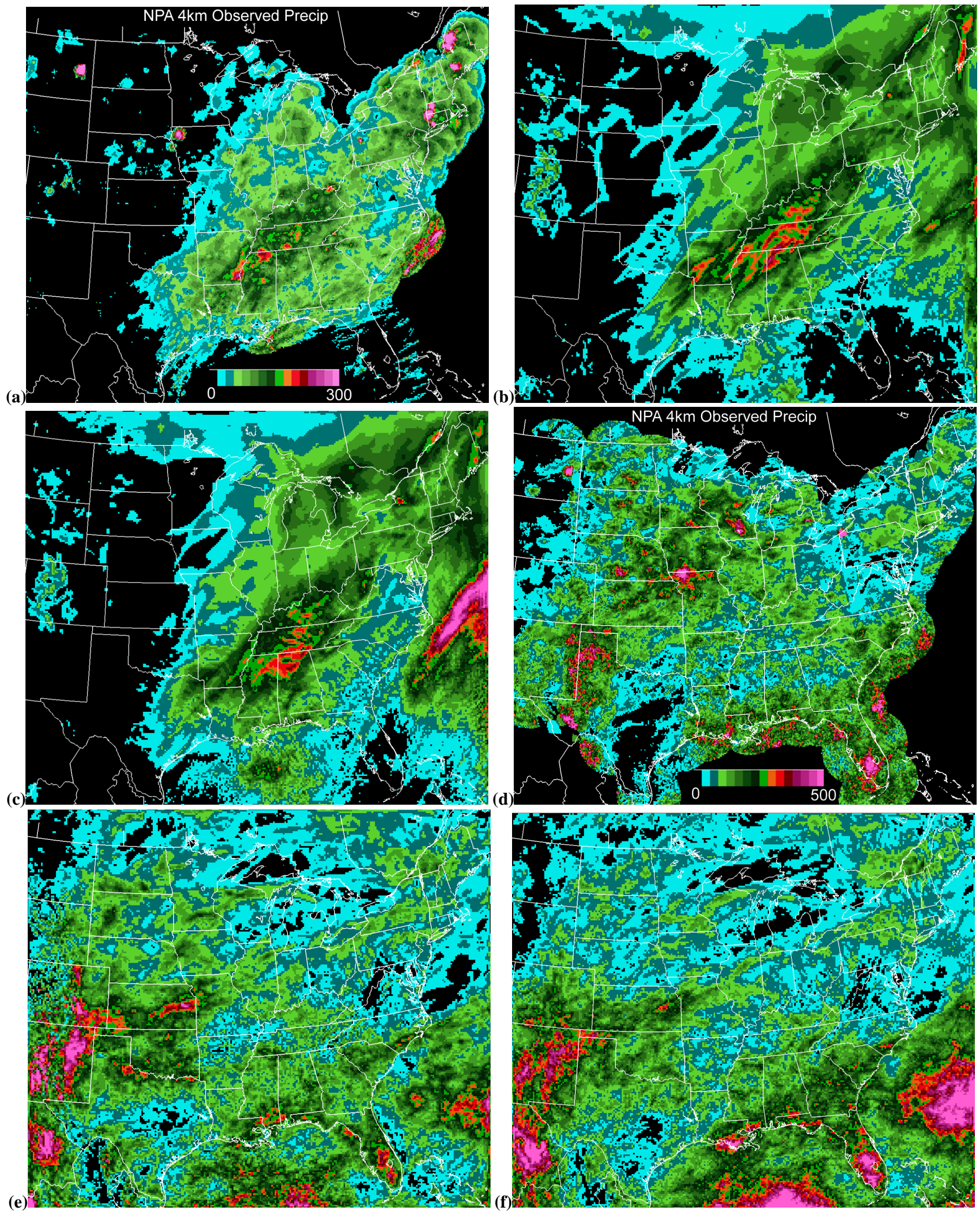

Fig. 2. January 2006 monthly accumulated precipitation (cm) for (a) NPA observed, (b) MM5 predicted and (c) WRF predicted. August 2006 monthly accumulated precipitation $(\mathrm{cm})$ for $(\mathbf{d})$ NPA observed, (e) MM5 predicted and f) WRF predicted. 

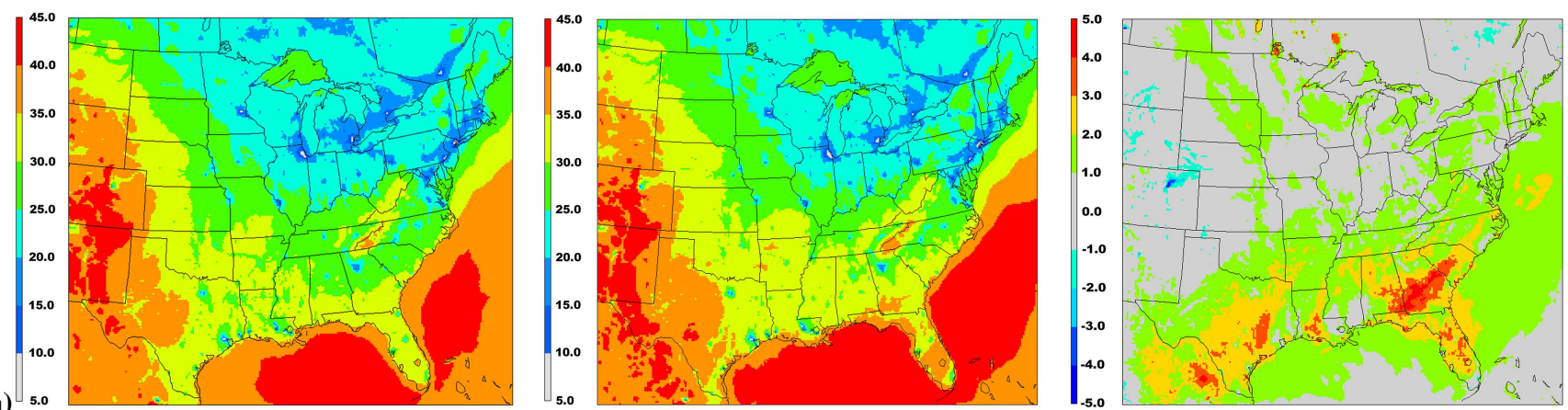

(a)
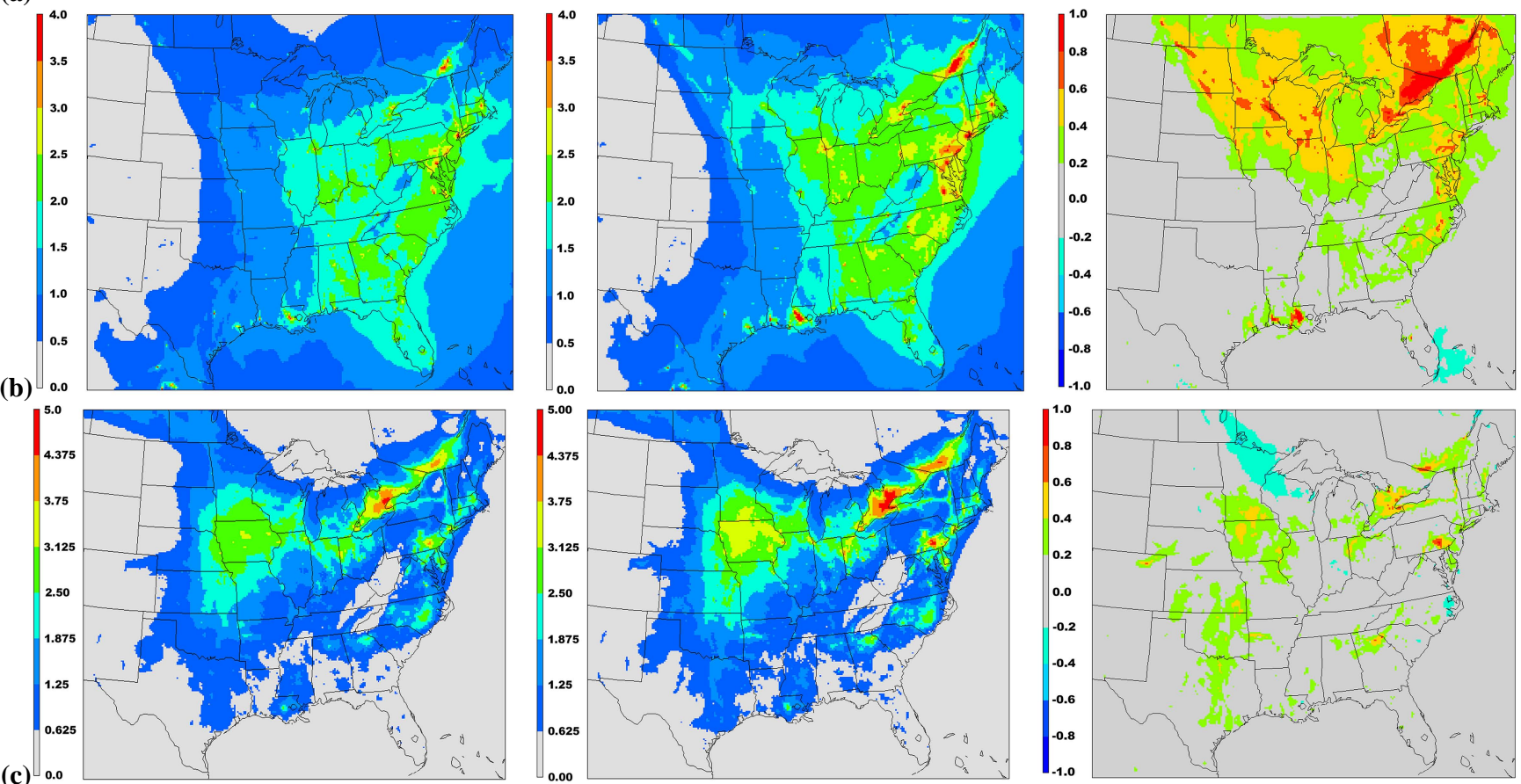

(c)
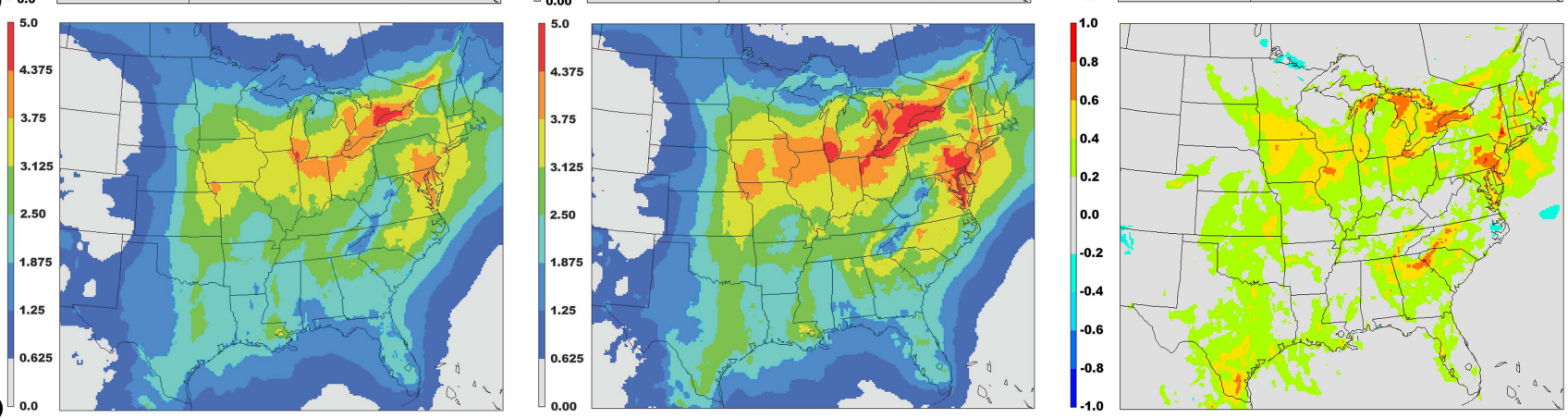

Fig. 3. Monthly average concentrations of MM5-CMAQ (left column), WRF-CMAQ (middle column) and WRF-CMAQ - MM5-CMAQ (right column) for (a) $\mathrm{O}_{3}(\mathrm{ppb})$, (b) $\mathrm{SO}_{4}^{2-}\left(\mu \mathrm{g} \mathrm{m}^{-3}\right)$, (c) $\mathrm{NO}_{3}^{-}\left(\mu \mathrm{g} \mathrm{m}^{-3}\right)$, (d) $\mathrm{TNO}_{3}\left(\mu \mathrm{g} \mathrm{m}^{-3}\right)$, (e) $\mathrm{TC}\left(\mu \mathrm{g} \mathrm{m}^{-3}\right)$, and (f) total PM $2.5 \mathrm{mass}^{-}$ $\left(\mu \mathrm{g} \mathrm{m}^{-3}\right)$ for January 2006.

of the air-mass at the beginning of the month, after which a dryer air-mass dominated most of the eastern United States. The diurnal bias in 2-m $T$ (Fig. 1d) is higher during the nighttime hours and lower during the daytime hours for the WRF simulation, while the $w$ bias is significantly reduced in the WRF model simulation during most of the day. Although the bias in 10-m WS is similar throughout the afternoon, the MM5 simulation has slightly less bias during the overnight and early morning hours. See Gilliam and Pleim (2010) for additional details regarding the causes for the differences in performance. 


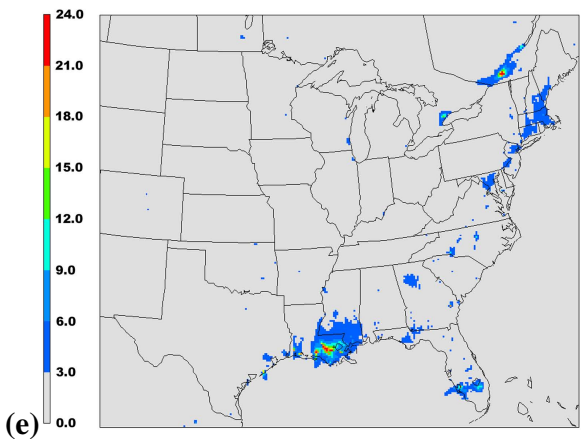

(e)

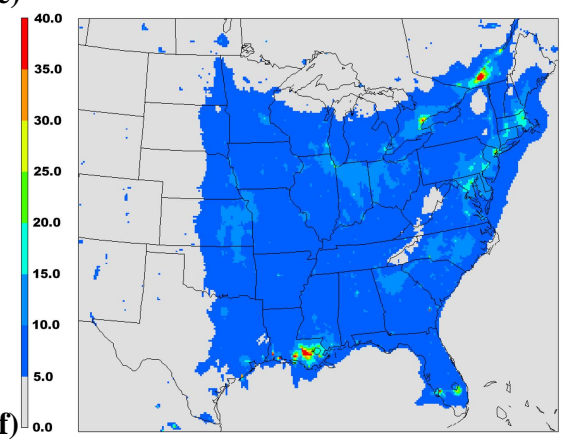

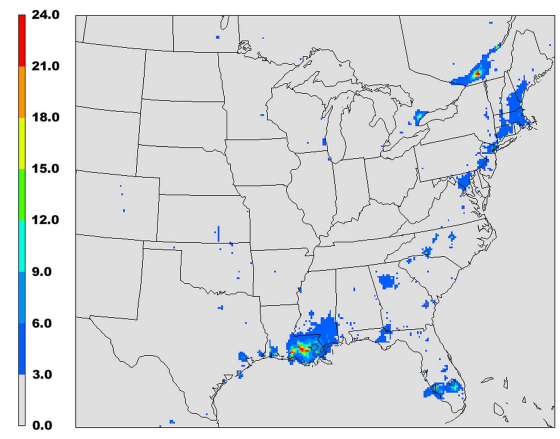

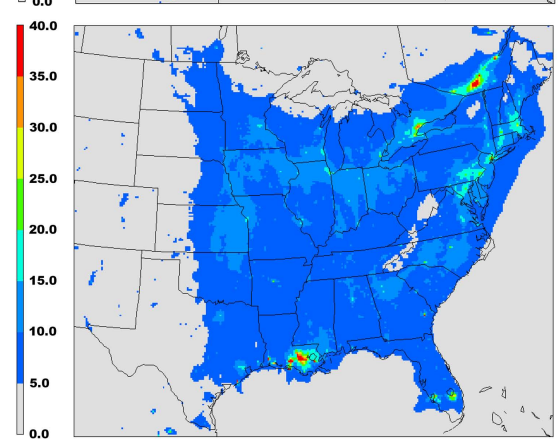

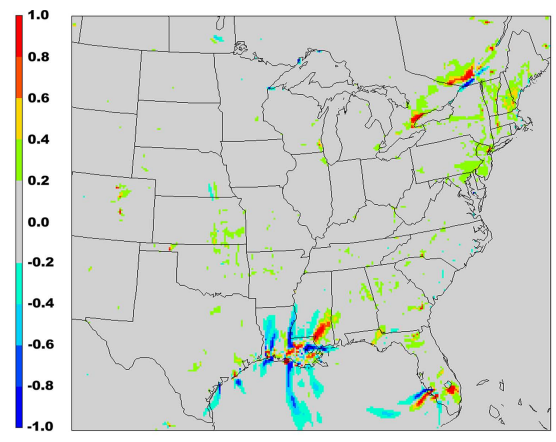

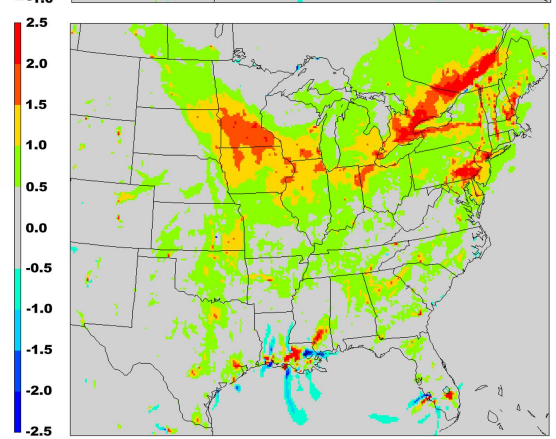

Fig. 3. Continued.

Comparison of the monthly precipitation for August (Fig. 2d-f) shows greater variability compared to January, which is expected due to the convective nature of summertime precipitation. The WRF model simulation (Fig. 2f) predicts greater precipitation over the southeast United States and offshore as compared to the MM5 simulation (Fig. 2e) and the observations (Fig. 2d), while the MM5 simulation has slightly higher predicted precipitation over the lower Midwest as compared to WRF model simulation. Both models overpredict precipitation in the lower Midwest and underpredict precipitation in the upper Midwest and western Great Lakes regions. Overall, the performance of the MM5 and WRF model simulations for January and August is similar, and generally compares well with the observations. This result is similar to the conclusions of Gilliam and Pleim (2010), in which they note similar performance for the MM5 and WRF model simulations for the two months.

\section{CMAQ model performance assessment}

\subsection{January}

\subsubsection{Ozone $\left(\mathrm{O}_{3}\right)$}

For January, $\mathrm{O}_{3}$ predictions are generally higher in the WRFCMAQ simulation, particularly across the southern portion of the model domain, where increases in monthly average $\mathrm{O}_{3}$ mixing ratios of $2 \mathrm{ppb}$ or more are present (Fig. 3a). The result is larger bias and error in the WRF-CMAQ simulation versus the MM5-CMAQ simulation (Table 2). Both simulations overpredict hourly $\mathrm{O}_{3}$ on average, indicated by the positive NMdnB and MdnB for both simulations; however the NMdnB and MdnB are $3.7 \%$ and 0.85 ppb higher for the WRF-CMAQ simulation, respectively. For maximum 8-h average $\mathrm{O}_{3}$, the $\mathrm{NMdnB}$ and $\mathrm{MdnB}$ are $3.7 \%$ and $1.19 \mathrm{ppb}$ higher for the WRF-CMAQ simulation. The error is similar between the two simulations for both measures of $\mathrm{O}_{3}$.

Comparison of the $\mathrm{O}_{3}$ dry deposition from the two simulations revealed that the higher predicted $\mathrm{O}_{3}$ mixing ratios over the southern portion of the domain in WRF-CMAQ simulation are due to less $\mathrm{O}_{3}$ dry deposition in the WRF-CMAQ simulation, which results in higher ambient $\mathrm{O}_{3}$ mixing ratios. There are significant differences in the way the vegetation fraction and leaf area index (LAI) are parameterized in the PX LSM between the MM5 and WRF implementations. Both models use satellite-derived vegetation coverage to scale these vegetation parameters in areas dominated by crops. However, the parameterizations differ such that vegetation fraction and LAI are set to minimum values in the winter in all areas in WRF but maintain higher values in the southern-most areas (Gulf coast and Florida) in MM5. The result is less $\mathrm{O}_{3}$ dry deposition in the WRF-CMAQ simulation due to less stomatal uptake (a result of the less vegetation and LAI) as compared to the MM5-CMAQ simulation, which in turn results in higher ambient $\mathrm{O}_{3}$ mixing ratios. The WRF parameterization is being re-assessed and may be revised to be more like the MM5 parameterization in the future. 

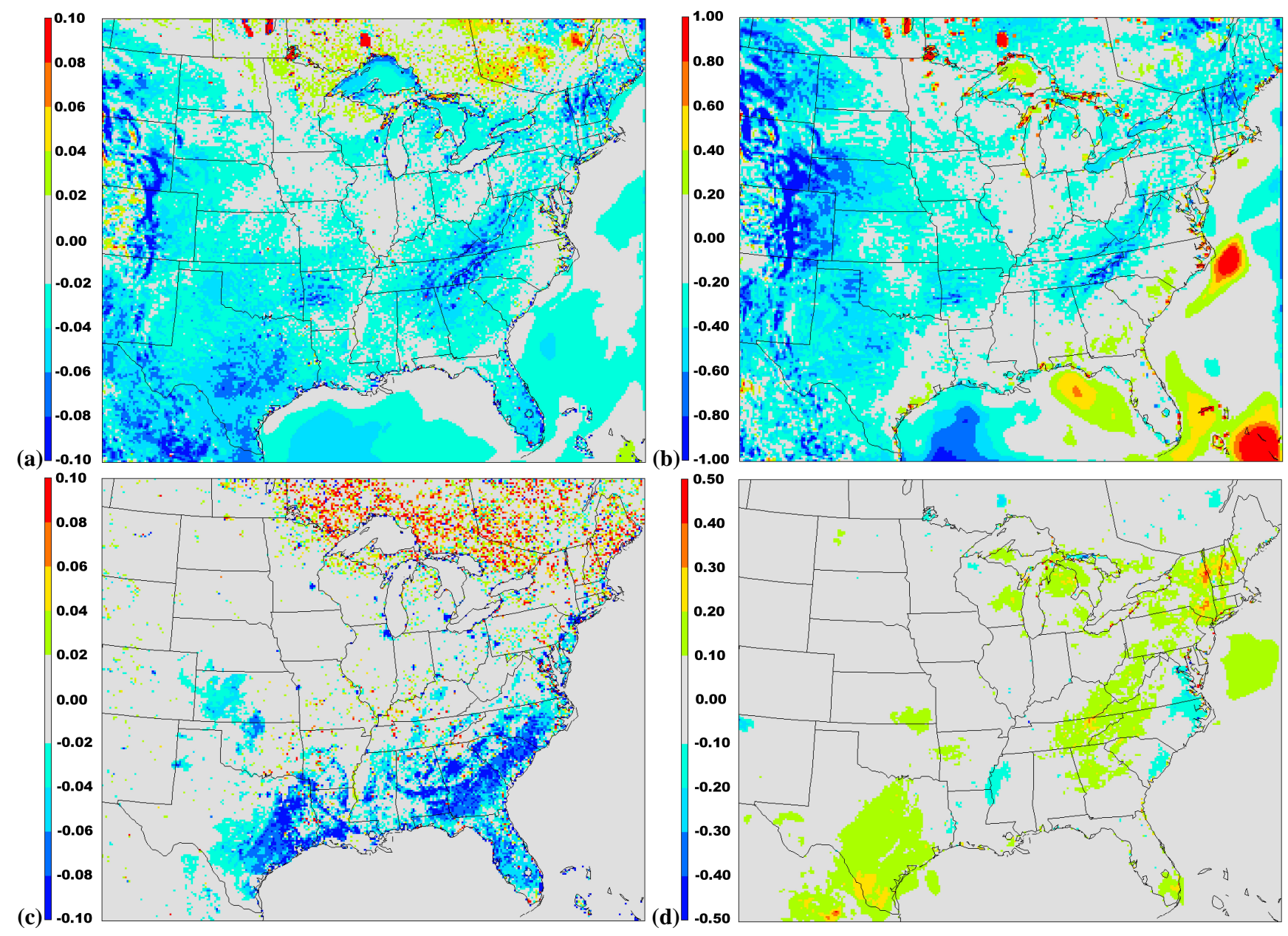

Fig. 4. Difference in monthly average (WRF - MM5) (a) $u_{*}\left(\mathrm{~m} \mathrm{~s}^{-1}\right)$, (b) layer one wind speed $\left(\mathrm{m} \mathrm{s}^{-1}\right)$ and (c) surface roughness length (m) for January 2006. (d) Difference in monthly average $\mathrm{TNO}_{3}\left(\mu \mathrm{g} \mathrm{m}^{-3}\right)$ between the MM5-CMAQ simulation using $u_{*}$ values calculated by WRF and the original MM5-CMAQ simulation for January 2006.

\subsubsection{Fine particulate sulfate $\left(\mathrm{SO}_{4}^{2-}\right)$}

Figure $3 \mathrm{~b}$ shows the predicted monthly average concentrations of particulate $\mathrm{SO}_{4}^{2-}$ for January between the two CMAQ simulations. Predictions of $\mathrm{SO}_{4}^{2-}$ are generally higher in the WRF-CMAQ simulation, with the exception of a small area off the coast of southern Florida. The largest differences occur over the northern portion of the domain, where areas of greater than $1 \mu \mathrm{g} \mathrm{m}^{-3}$ difference in monthly average $\mathrm{SO}_{4}^{2-}$ exist. While both simulations underpredict $\mathrm{SO}_{4}^{2-}$ on average (Table 2), the underprediction is smaller in WRF-CMAQ simulation, with a NMdnB that is 4.6-10.0\% lower and a MdnB that is $0.05-0.20 \mu \mathrm{g} \mathrm{m}^{-3}$ lower than in the MM5-CMAQ simulation. The error is also smaller in the WRF-CMAQ simulation, with the NMdnE 1.1-5.0\% lower and the MdnE 0.03-0.10 $\mu \mathrm{g} \mathrm{m}^{-3}$ lower than the MM5CMAQ simulation.
The higher predicted concentrations of particulate $\mathrm{SO}_{4}^{2-}$ in the WRF-CMAQ simulation appear to be related primarily to a combination of greater predicted cloud fraction and less $\mathrm{SO}_{4}^{2-}$ wet deposition (Fig. 4b) than in the MM5-CMAQ simulation. A comparison of the resolved clouds between the MM5 and WRF model simulations reveal a large area over the upper Midwest and central Canada where the predicted cloud fraction in WRF is notably greater than MM5. The result is more in-cloud aqueous $\mathrm{SO}_{4}^{2-}$ production in that region, which results in the higher predicted $\mathrm{SO}_{4}^{2-}$ concentrations shown in Fig. 3b. The higher $\mathrm{SO}_{4}^{2-}$ concentrations along the east coast of the United States and in Louisiana are also related to differences in the predicted cloud fraction. In the Northeast and eastern Canada, less $\mathrm{SO}_{4}^{2-}$ wet deposition (Fig. 4b) in the WRF-CMAQ simulation results in higher particulate $\mathrm{SO}_{4}^{2-}$ concentrations in that region. 
Table 2. Statistics of RMSE, NMdnB, NMdnE, MdnB and MdnE for fine particulate and wet deposition species for January 2006. MM5 indicates the MM5-CMAQ simulation; WRF indicates the WRF-CMAQ simulation. MdnB and MdnE values are in $\mathrm{ppb}$ for $\mathrm{O}_{3}, \mu \mathrm{g} \mathrm{m}^{-3}$ for aerosol species, $\mathrm{mm}$ for precipitation and $\mathrm{kg} \mathrm{ha}^{-1}$ for wet deposition species.

\begin{tabular}{|c|c|c|c|c|c|c|c|c|c|c|}
\hline \multirow{2}{*}{ Species } & \multirow{2}{*}{ Network } & \multirow{2}{*}{ \# of Obs } & \multicolumn{2}{|c|}{$\mathrm{NMdnB}(\%)$} & \multicolumn{2}{|c|}{ NMdnE (\%) } & \multicolumn{2}{|c|}{ MdnB } & \multicolumn{2}{|c|}{ MdnE } \\
\hline & & & MM5 & WRF & MM5 & WRF & MM5 & WRF & MM5 & WRF \\
\hline \multirow{2}{*}{$\begin{array}{c}\mathrm{O}_{3} \text { (Hourly) } \\
\mathrm{O}_{3} \text { (8-h Max) }\end{array}$} & \multirow{2}{*}{ AQS } & 245129 & 8.2 & 11.9 & 25.4 & 26.5 & 1.88 & 2.73 & 5.85 & 6.10 \\
\hline & & 9925 & 1.5 & 5.2 & 12.9 & 12.8 & 0.5 & 1.69 & 4.19 & 4.16 \\
\hline \multirow{3}{*}{$\mathrm{SO}_{4}^{2-}$} & IMPROVE & 787 & -6.7 & -1.8 & 22.8 & 19.4 & -0.08 & -0.03 & 0.27 & 0.23 \\
\hline & CSN & 1034 & -13.2 & -5.8 & 24.8 & 23.7 & -0.29 & -0.13 & 0.55 & 0.52 \\
\hline & CASTNet & 247 & -12.8 & -2.8 & 17.3 & 12.4 & -0.26 & -0.06 & 0.35 & 0.25 \\
\hline \multirow{2}{*}{$\mathrm{NO}_{3}^{-}$} & IMPROVE & 787 & -9.2 & -8.2 & 73.9 & 71.1 & -0.04 & -0.03 & 0.29 & 0.28 \\
\hline & CSN & 994 & -17.2 & -7.0 & 48.0 & 46.0 & -0.24 & -0.10 & 0.68 & 0.65 \\
\hline $\mathrm{TNO}_{3}$ & CASTNet & 247 & 8.3 & 17.4 & 19.1 & 21.6 & 0.19 & 0.40 & 0.43 & 0.49 \\
\hline \multirow{2}{*}{$\mathrm{TC}$} & IMPROVE & 820 & -16.8 & -15.4 & 41.7 & 41.7 & -0.14 & -0.13 & 0.36 & 0.36 \\
\hline & CSN & 941 & 7.8 & 14.9 & 38.8 & 43.9 & 0.16 & 0.30 & 0.77 & 0.87 \\
\hline \multirow{2}{*}{$\mathrm{PM}_{2.5}$} & IMPROVE & 859 & 4.6 & 9.4 & 36.0 & 39.4 & 0.19 & 0.39 & 1.51 & 1.65 \\
\hline & CSN & 883 & 1.6 & 10.2 & 28.6 & 31.1 & 0.16 & 1.02 & 2.86 & 3.11 \\
\hline Precipitation & \multirow{4}{*}{ NADP } & 711 & 6.0 & 3.2 & 45.0 & 40.4 & 0.53 & 0.28 & 4.00 & 3.59 \\
\hline WetD Sulf. & & 576 & 6.2 & -0.1 & 49.2 & 44.6 & 0.01 & 0.00 & 0.06 & 0.06 \\
\hline WetD Amm. & & 576 & -17.4 & 16.9 & 49.8 & 49.8 & 0.00 & 0.00 & 0.01 & 0.01 \\
\hline WetD Nitr. & & 576 & 2.3 & -2.9 & 47.8 & 45.8 & 0.00 & 0.00 & 0.06 & 0.06 \\
\hline
\end{tabular}

\subsubsection{Fine particulate nitrate $\left(\mathrm{NO}_{3}^{-}\right)$and total nitrate $\left(\mathrm{TNO}_{3}\right)$}

$\mathrm{NO}_{3}^{-}$tends to constitute the largest component of fine particulate mass in the eastern United States during the cold season. Figure $3 \mathrm{c}$ shows the predicted monthly average $\mathrm{NO}_{3}^{-}$concentrations for the two simulations for January, along with the difference between the two model simulations. The WRF-CMAQ simulation predicts higher $\mathrm{NO}_{3}^{-}$concentrations on average; however the differences are generally small, with only a few localized areas where the differences reach $1 \mu \mathrm{g} \mathrm{m}^{-3}$ or greater. Since $\mathrm{NO}_{3}^{-}$is underpredicted in both simulations (Table 2), the higher predicted concentrations in the WRF-CMAQ simulation result in an improvement of both the bias and error. The NMdnB is more than $10 \%$ lower at the CSN sites in the WRF-CMAQ simulation as compared to the MM5-CMAQ simulation, while the difference in NMdnB at IMPROVE network sites is less than a percent. However, the difference in the NMdnE is larger at the IMPROVE network sites (5.4\%) than at the CSN sites $(1.7 \%)$.

For $\mathrm{TNO}_{3}$ (Fig. 3d), the differences between the two simulations are considerably larger and more widespread than for $\mathrm{NO}_{3}^{-}$alone, indicating significant differences in the $\mathrm{HNO}_{3}$ predictions. The higher predicted $\mathrm{HNO}_{3}$ concentrations in the WRF-CMAQ simulation result in an increase in the $\mathrm{TNO}_{3}$ bias compared to the MM5-CMAQ simulation, as
$\mathrm{TNO}_{3}$ was already overpredicted in both simulations. The $\mathrm{NMdnB}$ and $\mathrm{MdnB}$ for $\mathrm{TNO}_{3}$ at CASTNet sites are 9.1\% and $0.21 \mu \mathrm{g} \mathrm{m}^{-3}$ higher, respectively, in the WRF-CMAQ simulation. The NMdbE and MdnE are also higher in the WRF-CMAQ simulation, but to a slightly lesser degree. The difference in predicted $\mathrm{TNO}_{3}$ concentrations may be the result of differences in predicted wind speeds, PBL heights and the overall stability between the two simulations. Comparisons of surface wind speeds showed that over land the wind speeds are on average lower in the WRF simulation in January (Fig. 1b), which results in less mixing and hence higher surface concentrations for the various pollutants. An examination of PBL heights between the two simulations showed that PBL heights over land are on average lower in the WRF simulation, which would tend to concentrate pollutants at the surface and lead to higher concentrations as well.

Additionally, a difference in the calculation of dry deposition velocity, which is very high for $\mathrm{HNO}_{3}$ and limited primarily by the aerodynamic resistance, likely plays a smaller role in the difference in predicted $\mathrm{HNO}_{3}$ between the two simulations in January. Aerodynamic resistance is strongly dependent on the friction velocity $\left(u_{*}\right)$ that is, on average, higher in MM5 than WRF in January (Fig. 4a). The higher $u_{*}$ values in MM5, particularly at night when wind speed is often very light, leads to greater dry deposition of $\mathrm{HNO}_{3}$ in the MM5-CMAQ simulation. In the MM5 model, the minimum wind speed value in the $u_{*}$ calculation is set to $1.0 \mathrm{~m} \mathrm{~s}^{-1}$, 
while in the WRF model the minimum is set to $0.1 \mathrm{~m} \mathrm{~s}^{-1}$. It was suspected that the higher minimum value for wind speed in MM5 was responsible for the higher $u_{*}$ values. To test this, a simulation was performed for January in which the minimum wind speed value in MM5 was changed from $1.0 \mathrm{~m} \mathrm{~s}^{-1}$ to $0.1 \mathrm{~m} \mathrm{~s}^{-1}$ (the same as the WRF model). However, the change in the minimum wind speed threshold resulted in little change in the calculated $u_{*}$ values in the MM5 simulation. Additional analysis into the differences in $u_{*}$ suggest that a combination of lower wind speeds (Fig. 4b) and smaller surface roughness lengths (Fig. 4c) in the WRF model simulation may be primarily responsible for the lower $u_{*}$ values.

As an additional sensitivity to test the impact that $u_{*}$ has on the $\mathrm{HNO}_{3}$ dry deposition in the CMAQ model, the MM5CMAQ simulation was re-run using the $u_{*}$ and aerodynamic resistance values calculated by the WRF model in place of the values calculated by MM5 in the m3dry and aero_depv subroutines in the CMAQ model code. Results from the new MM5-CMAQ simulation showed that $\mathrm{HNO}_{3}$ concentrations increased on average across the domain, particularly in Texas, the mid-Atlantic, the Northeast, and the Great Lakes regions (Fig. 4d). The average increase in $\mathrm{HNO}_{3}$ was between 0.10 and $0.40 \mu \mathrm{g} \mathrm{m}^{-3}$, with the largest increase being $0.60 \mu \mathrm{g} \mathrm{m}^{-3}$. These increases are smaller than the majority of differences in $\mathrm{TNO}_{3}$ between the MM5-CMAQ and WRFCMAQ simulations, which generally range between 0.20 and $0.80 \mu \mathrm{g} \mathrm{m}^{-3}$. Overall, the higher concentrations of $\mathrm{TNO}_{3}$ in January appear to be most likely due to the lower wind speeds and PBL heights in the WRF-CMAQ simulation, with the change in $\mathrm{HNO}_{3}$ dry deposition due to differences in $u_{*}$ being only a secondary contributor to the differences.

\subsubsection{Total carbon (TC)}

Figure $3 \mathrm{e}$ shows the predicted monthly average concentrations of TC for the two simulations for January. Differences are generally small and isolated; however, there are several areas where larger differences occur, specifically in the Northeast, along the Gulf of Mexico coast and in southern Florida. Although the differences in TC predictions are not very widespread, they do result in a larger bias at the CSN sites for the WRF-CMAQ simulation, with the NMdnB and MdnB $7.0 \%$ and $0.15 \mu \mathrm{g} \mathrm{m}^{-3}$ higher, respectively, than the MM5-CMAQ simulation (Table 2). The error is also higher at the CSN sites in the WRF-CMAQ simulation. At the IMPROVE network sites, the bias and error are very similar between the two simulations. The larger bias at the CSN sites in the WRF-CMAQ simulation is due mainly to higher predicted TC concentrations in the Northeast, Great Lakes and Mid-Atlantic regions. Some of these differences are not apparent from Fig. 3e, as the average difference in TC between the two simulations is $0.15 \mu \mathrm{g} \mathrm{m}^{-3}$, which falls within the gray shading on the figure.

\subsubsection{Total fine particulate mass $\left(\mathbf{P M}_{2.5}\right)$}

Figure $3 \mathrm{f}$ shows the monthly average predictions in total $\mathrm{PM}_{2.5}$ mass for January for the two CMAQ simulations. The differences in predicted total $\mathrm{PM}_{2.5}$ mass between the two simulations are dominated by the differences in $\mathrm{SO}_{4}^{2-}, \mathrm{TNO}_{3}$ and TC predictions already noted. The MM5-CMAQ simulation has a slight bias in predicted total $\mathrm{PM}_{2.5}$ mass (Table 2). The predicted total $\mathrm{PM}_{2.5}$ mass is higher in the WRF-CMAQ simulation, which results in an increase in the NMdnB and $\mathrm{MdnB}$ of $5.0-8.6 \%$ and $0.21-0.87 \mu \mathrm{g} \mathrm{m}^{-3}$, respectively.

Regarding the calculation of total $\mathrm{PM}_{2.5}$ mass from the raw CMAQ model output, $\mathrm{PM}_{2.5}$ concentrations are calculated as a weighted sum of 40 different chemical species tracked within the CMAQv4.7 aerosol module (Eq. 5).

$$
\begin{aligned}
\mathrm{PM}_{2.5}= & \mathrm{SO}_{i, j, k}+\mathrm{NO}_{i, j, k}+\mathrm{NH} 4_{i, j, k}+\mathrm{Na}_{i, j, k}+\mathrm{Cl}_{i, j, k} \\
& +\mathrm{EC}_{i, j}+1.2 \mathrm{ORGPA}_{i, j}+\mathrm{SOA}_{j}+\mathrm{Unspec}_{j, k}+\mathrm{Soil}_{k}
\end{aligned}
$$

The subscripts $i, j$, and $k$ represent the Aitken, accumulation, and coarse modes of the particle size distribution, respectively; Na represents a sum of all sea-salt cations, including sodium, potassium, magnesium, and calcium; ORGPA represents the directly-emitted organic carbon; the multiplicative factor of 1.2 approximates the oxidation of ORGPA that occurs during atmospheric transport, a process that is not represented in CMAQ v4.7; SOA represents the sum of 19 secondary organic species described by Carlton et al. (2010); Unspec ${ }_{j}$ and Unspec ${ }_{k}$ are the model species A25J and ACORS, respectively, which represent directly-emitted PM that is not chemically speciated in the national emissions inventory. In Eq. (5), each species with a subscript $i$ is multiplied by a factor, PM25AT, to remove the portion of the Aitken mode mass distribution that exceeds $2.5 \mu \mathrm{m}$ in aerodynamic diameter. Likewise, all species with subscript $j$ are multiplied by PM25AC and the species with subscript $k$ are multiplied by PM25CO. These three scaling factors have values between 0 and 1 , which are computed in each grid cell during each hour of the model simulation following the description by Jiang (2006), and written to the aerosol diagnostic output file.

\subsubsection{Wet deposition species}

Figure 4 shows the predicted monthly precipitation and $\mathrm{SO}_{4}^{2-}, \mathrm{NO}_{3}^{-}$and $\mathrm{NH}_{4}^{+}$wet deposition for January for the two CMAQ model simulations. The largest differences in precipitation (Fig. 4a) are generally limited to areas over the Atlantic Ocean and Gulf of Mexico, with smaller differences occurring over the eastern United States. Most of the significant differences in precipitation over land occur in the southern portion of the domain, where the WRF model generally predicts less precipitation than MM5. The bias and error for precipitation (Table 2) is similar for both simulations, with 
Table 3. Statistics of RMSE, NMdnB, NMdnE, MdnB and MdnE for fine particulate and wet deposition species for August 2006 . MM5 indicates the MM5-CMAQ simulation; WRF indicates the WRF-CMAQ simulation. MdnB and MdnE values are in $\mathrm{ppb}$ for $\mathrm{O}_{3}, \mu \mathrm{g} \mathrm{m}^{-3}$ for aerosol species, $\mathrm{mm}$ for precipitation and $\mathrm{kg} \mathrm{ha}^{-1}$ for wet deposition species.

\begin{tabular}{cccrrrrrrrr}
\hline \multirow{2}{*}{ Species } & \multirow{2}{*}{ Network } & \multirow{2}{*}{ \# of Obs } & \multicolumn{2}{c}{ NMdnB $(\%)$} & \multicolumn{2}{c}{ NMdnE $(\%)$} & \multicolumn{2}{c}{ MdnB } & \multicolumn{2}{c}{ MdnE } \\
& & & MM5 & WRF & MM5 & WRF & MM5 & WRF & MM5 & WRF \\
\hline $\mathrm{O}_{3}$ (Hourly) & \multirow{2}{*}{ AQS } & 598583 & 14.1 & 19.0 & 28.9 & 31.1 & 4.36 & 5.88 & 8.95 & 9.65 \\
$\mathrm{O}_{3}$ (8-h Max) & 24413 & 1.2 & 5.4 & 13.3 & 14.2 & 0.57 & 2.62 & 6.47 & 6.89 \\
\hline \multirow{2}{*}{$\mathrm{SO}_{4}^{2-}$} & IMPROVE & 531 & -8.5 & -8.6 & 38.5 & 34.5 & -0.12 & -0.12 & 0.53 & 0.48 \\
& CSN & 932 & -6.7 & -8.0 & 25.0 & 23.1 & -0.24 & -0.28 & 0.89 & 0.82 \\
& CASTNet & 251 & -11.8 & -21.1 & 14.9 & 21.6 & -0.57 & -1.01 & 0.72 & 1.06 \\
\hline \multirow{2}{*}{$\mathrm{NO}_{3}^{-}$} & IMPROVE & 531 & -51.7 & -44.9 & 73.0 & 70.8 & -0.07 & -0.06 & 0.10 & 0.10 \\
& CSN & 892 & -45.2 & -30.1 & 63.0 & 63.4 & -0.18 & -0.12 & 0.25 & 0.25 \\
\hline $\mathrm{TNO}_{3}$ & CASTNet & 251 & 10.9 & 28.4 & 32.0 & 40.1 & 0.18 & 0.46 & 0.52 & 0.65 \\
\hline \multirow{2}{*}{$\mathrm{TC}^{2}$} & IMPROVE & 701 & -47.7 & -42.0 & 53.5 & 47.3 & -0.71 & -0.62 & 0.80 & 0.70 \\
& CSN & 896 & -44.7 & -37.3 & 46.9 & 41.5 & -1.40 & -1.17 & 1.47 & 1.30 \\
\hline \multirow{2}{*}{$\mathrm{PM}_{2.5}$} & IMPROVE & 693 & -32.7 & -28.1 & 38.2 & 34.1 & -2.10 & -1.81 & 2.45 & 2.19 \\
& CSN & 809 & -22.1 & -14.9 & 30.9 & 27.5 & -2.65 & -1.79 & 3.71 & 3.30 \\
\hline Precipitation & & 709 & 18.5 & 7.3 & 94.6 & 83.7 & 2.59 & 1.03 & 13.2 & 11.7 \\
WetD Sulf. & \multirow{2}{*}{ NADP } & 634 & 4.4 & 2.3 & 70.2 & 64.6 & 0.01 & 0.00 & 0.16 & 0.14 \\
WetD Amm. & 634 & -5.7 & -1.2 & 70.0 & 68.1 & 0.00 & 0.00 & 0.03 & 0.03 \\
WetD Nitr. & & 634 & -44.8 & -38.5 & 57.0 & 55.4 & -0.09 & -0.07 & 0.11 & 0.11 \\
\hline
\end{tabular}

the WRF simulation having slightly lower bias and error than the MM5 simulation.

The $\mathrm{SO}_{4}^{2-}, \mathrm{NO}_{3}^{-}$and $\mathrm{NH}_{4}^{+}$wet deposition are all lower in the WRF-CMAQ simulation, particularly in the Northeast, where large differences in precipitation were not observed. The $\mathrm{SO}_{4}^{2-}$ wet deposition (Fig. 4b) shows the largest and most widespread decrease, which results in an unbiased NMdnB and MdnB for the WRF-CMAQ simulation, versus a NMdnB of $6.8 \%$ and MdnB of $0.01 \mathrm{~kg} \mathrm{ha}^{-1}$ for the MM5CMAQ simulation (Table 2). The $\mathrm{NO}_{3}^{-}$and $\mathrm{NH}_{4}^{+}$wet deposition (Fig. $4 \mathrm{c}$ and d) show smaller differences in bias between the two simulations. The error is generally comparable for the two simulations, with the WRF-CMAQ simulation having slightly lower error for $\mathrm{SO}_{4}^{2-}$ and $\mathrm{NO}_{3}^{-}$wet deposition.

\subsection{August}

\subsubsection{Ozone $\left(\mathrm{O}_{3}\right)$}

The predicted monthly average $\mathrm{O}_{3}$ for August for the two CMAQ model simulations is shown in Fig. 5a, while the average observed and predicted diurnal mixing ratios for the entire domain are shown in Fig. 6. The predicted $\mathrm{O}_{3}$ mixing ratios in the WRF-CMAQ simulation are higher throughout a large portion of the domain, particularly in the southern and western portions of the domain, while there are only a few isolated areas where $\mathrm{O}_{3}$ mixing ratios were lower in the WRF-CMAQ simulation. The largest differences in predicted $\mathrm{O}_{3}$ mixing ratios occur along the Gulf of Mexico, where the difference in predicted monthly average $\mathrm{O}_{3}$ is greater than $4 \mathrm{ppb}$ over a widespread area, with some isolated areas of greater than $10 \mathrm{ppb}$ higher $\mathrm{O}_{3}$. Both simulations overpredict $\mathrm{O}_{3}$ (Table 3 ), however the overprediction is much larger for the hourly $\mathrm{O}_{3}$ than the maximum 8-h average $\mathrm{O}_{3}$ due to large overpredictions of $\mathrm{O}_{3}$ during the nighttime hours (Fig. 6). As expected, the bias is larger in the WRFCMAQ simulation, with a NMdnB 4.9 and $4.2 \%$ higher and a MdnB 2.0 and $1.5 \mathrm{ppb}$ higher than the MM5-CMAQ simulation for maximum 1-h and 8-h average $\mathrm{O}_{3}$, respectively. The error is also slightly higher in the WRF-CMAQ simulation. Figure 7 a shows the difference in the mean bias of hourly $\mathrm{O}_{3}$ (as compared to observations) at the AQS sites between the two simulations. The increase in mean bias is mainly limited to sites along the Gulf Coast, where the mean bias at some sites increases by as much as $16 \mathrm{ppb}$. For the rest of the domain, the change in mean bias is generally small. However, some slightly larger increases in mean bias are noted in the upper Great Lakes region.

The higher predicted $\mathrm{O}_{3}$ mixing ratios in the WRF-CMAQ simulation appear to be due to several differences between the MM5 and WRF model predictions. First, an analysis of the predicted cloud fraction (CFRAC) from each simulation showed that the predicted CFRAC from the WRFCMAQ simulation was on average less than that of the MM5CMAQ simulation. The smaller CFRAC in the WRF-CMAQ 


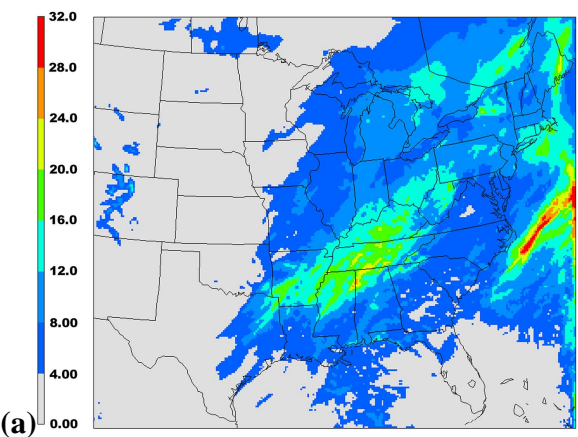

(a) 0.00

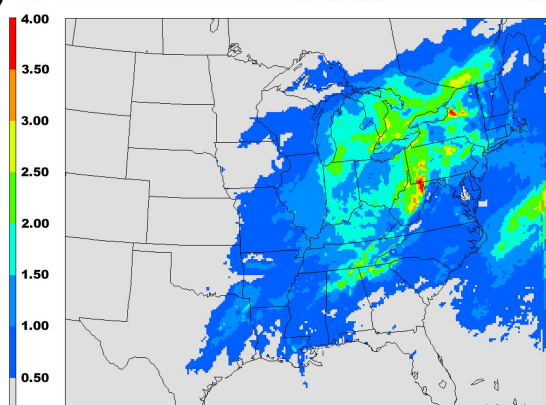

(b) $\square_{0.00}$

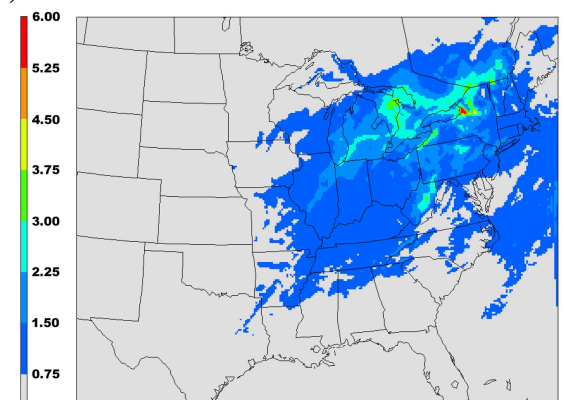

(c) $\square_{0.00}$

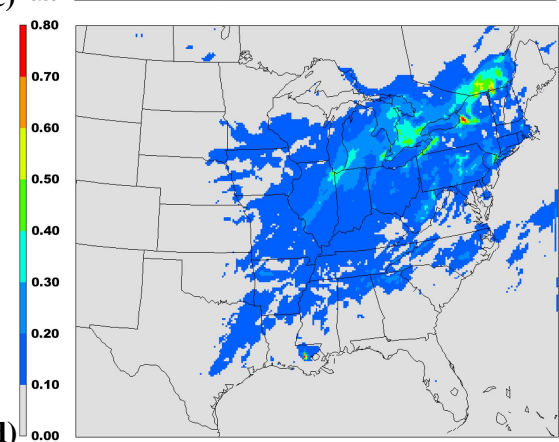

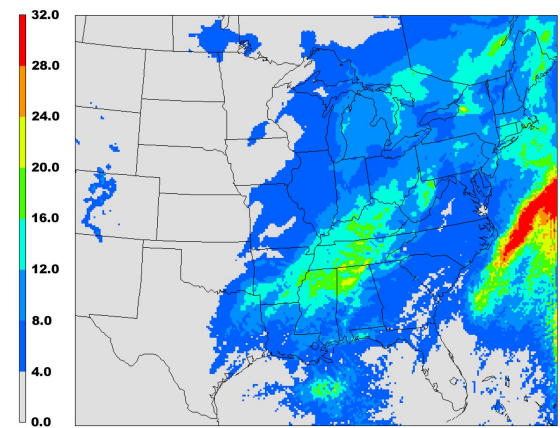
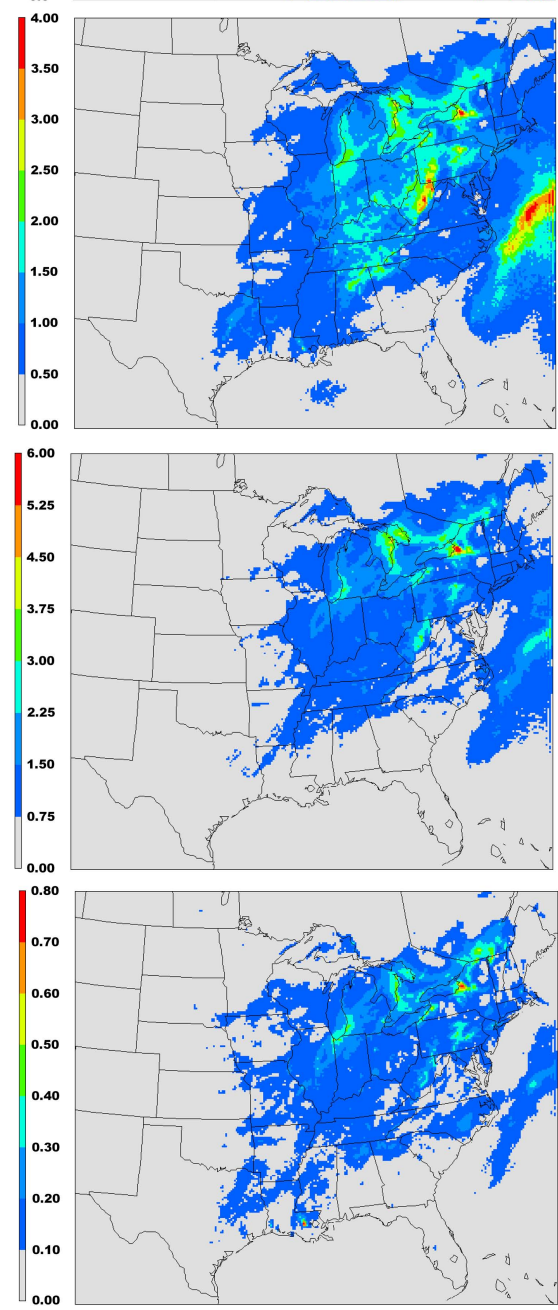
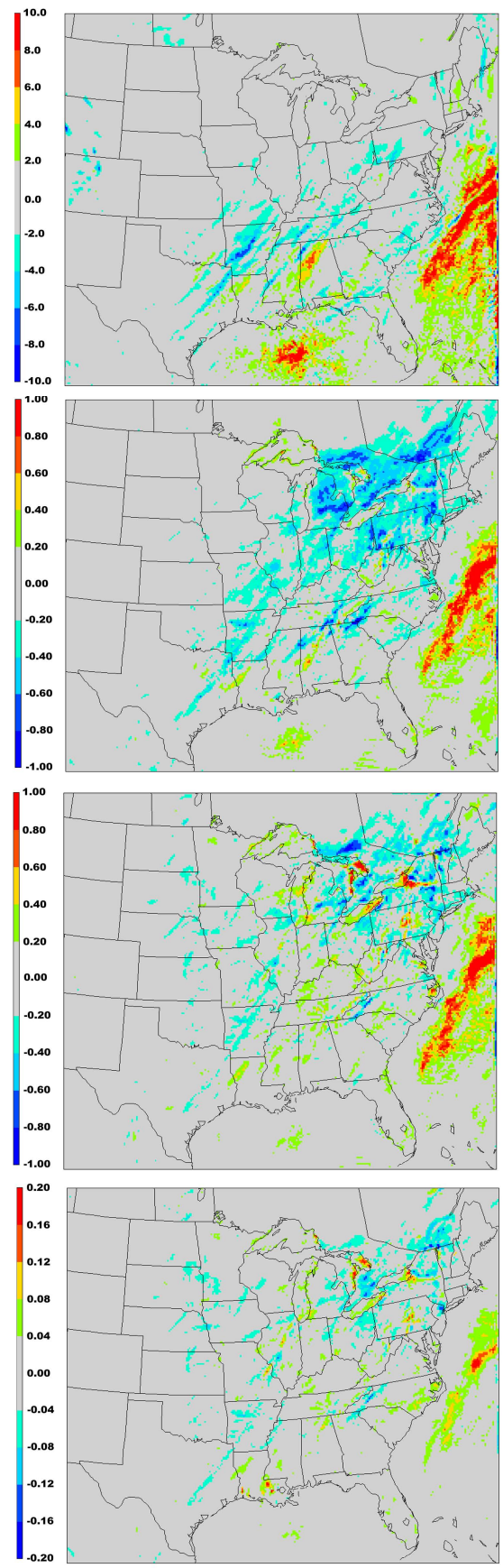

Fig. 5. Monthly average concentrations of MM5-CMAQ (left column), WRF-CMAQ (middle column) and WRF-CMAQ - MM5-CMAQ (right column) for (a) precipitation $(\mathrm{cm}),(\mathbf{b}) \mathrm{SO}_{4}^{2-}$ wet deposition $\left(\mathrm{kg} \mathrm{ha}^{-1}\right)$, (c) $\mathrm{NO}_{3}^{-}$wet deposition $\left(\mathrm{kg} \mathrm{ha}^{-1}\right)$ and $(\mathbf{d}) \mathrm{NH}_{4}^{+}$wet deposition $\left(\mathrm{kg} \mathrm{ha}^{-1}\right)$ for January 2006.

simulation is favorable for greater $\mathrm{O}_{3}$ production, as CFRAC is used in the calculation of the photolysis rate for $\mathrm{O}_{3}$, and less CFRAC can result in increased $\mathrm{O}_{3}$ photolysis. Although the CFRAC in the WRF-CMAQ simulation was on average less than the MM5-CMAQ simulation, it is difficult to quantify the exact impact the difference in CFRAC played in the differences in $\mathrm{O}_{3}$ mixing ratios between the two simulations.
Second, a comparison of surface solar radiation (SR) at the CASTNet sites showed that while both simulations overpredicted SR, the hourly SR during the daytime (7 a.m. to 7 p.m. LST) was on average 20 watts $\mathrm{m}^{-2}$ higher in the WRFCMAQ simulation than in the MM5-CMAQ simulation for August, suggesting less overall cloud cover in the WRFCMAQ simulation. The greater surface SR results in higher 
(a)
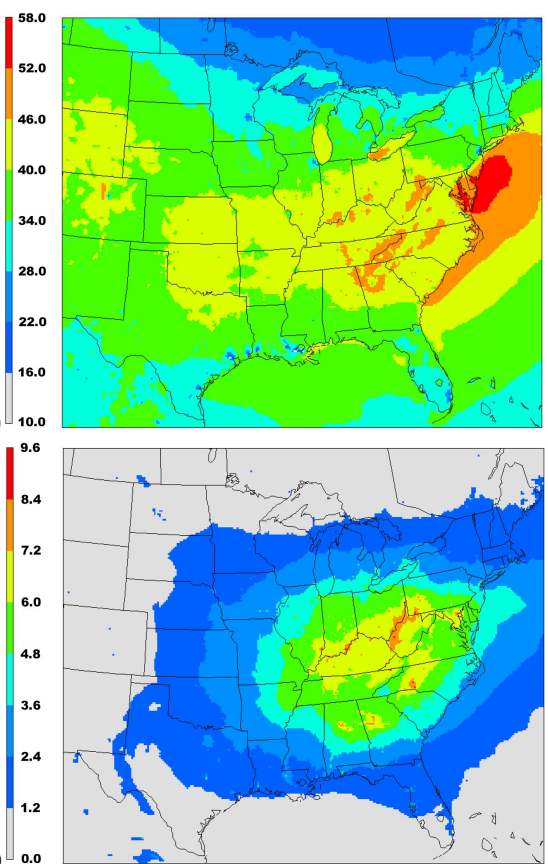

(b)

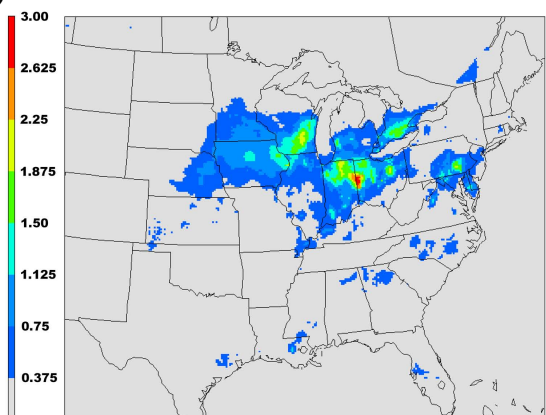

(c) $\square_{0.000}$

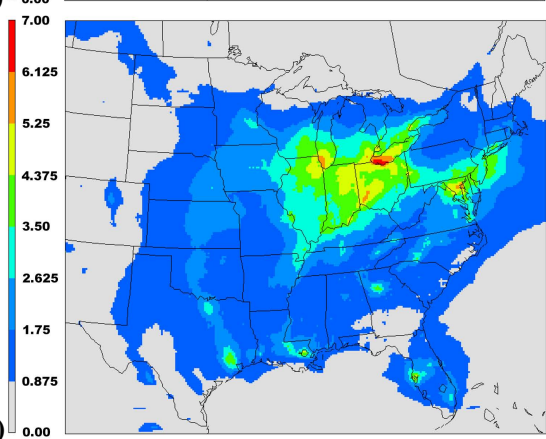

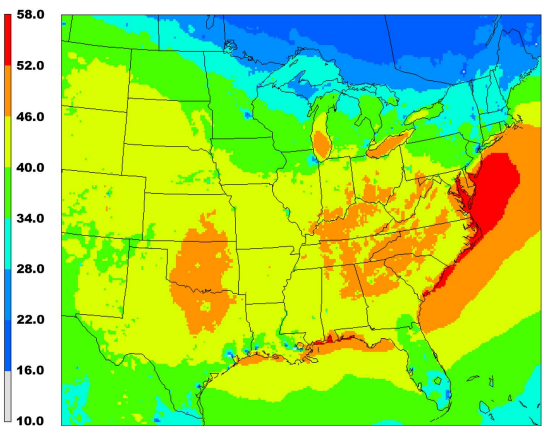
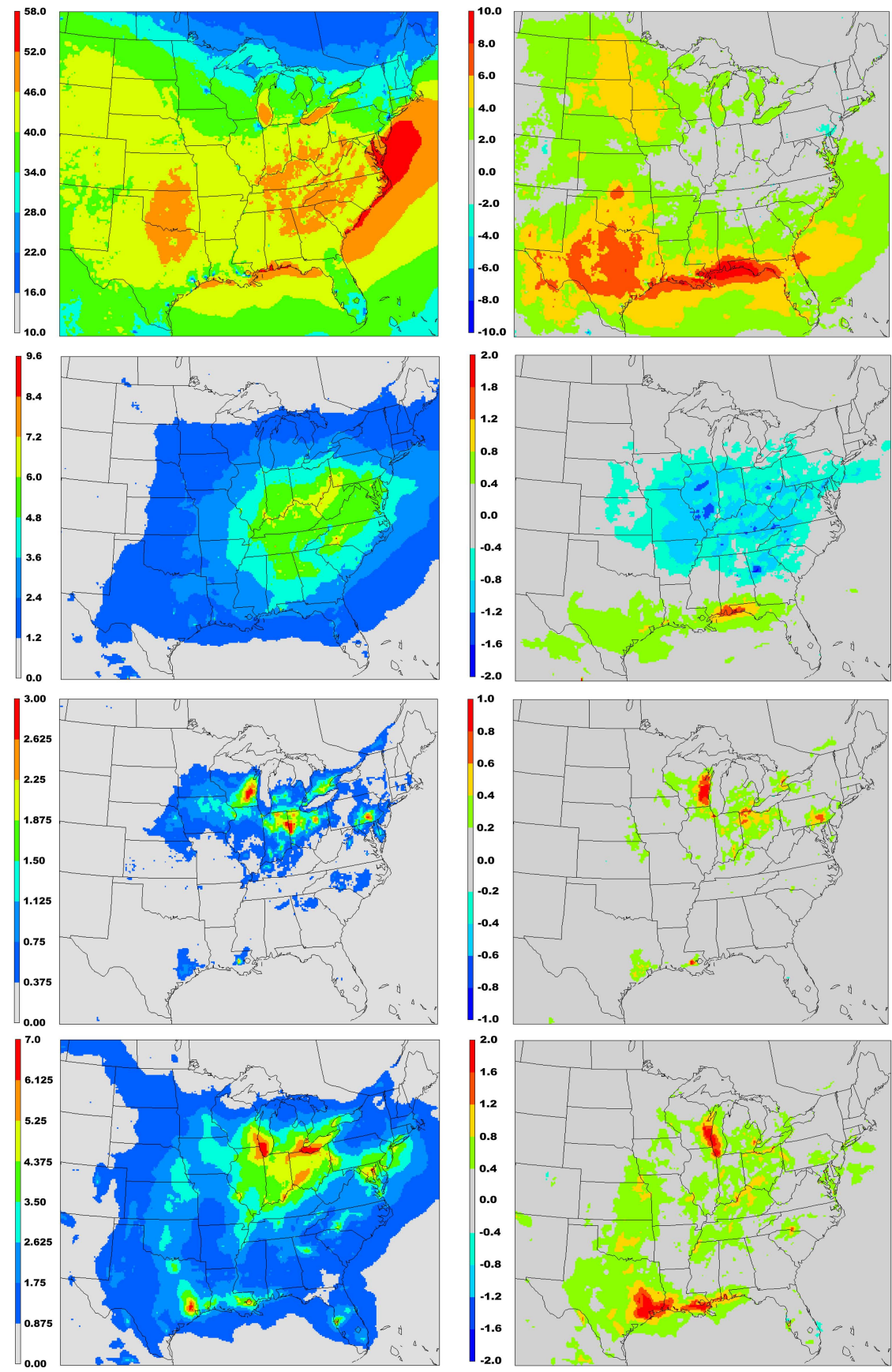

Fig. 6. Monthly average concentrations of MM5-CMAQ (left column), WRF-CMAQ (middle column) and WRF-CMAQ - MM5-CMAQ (right column) for (a) $\mathrm{O}_{3}(\mathrm{ppb})$, (b) $\mathrm{SO}_{4}^{2-}\left(\mu \mathrm{g} \mathrm{m}^{-3}\right)$, (c) $\mathrm{NO}_{3}^{-}\left(\mu \mathrm{g} \mathrm{m}^{-3}\right)$, (d) $\mathrm{TNO}_{3}\left(\mu \mathrm{g} \mathrm{m}^{-3}\right)$, (e) $\mathrm{TC}\left(\mu \mathrm{g} \mathrm{m}^{-3}\right)$ and (f) total $\mathrm{PM}_{2.5}$ mass $\left(\mu \mathrm{g} \mathrm{m}^{-3}\right)$ for January 2006.

surface temperatures in the WRF-CMAQ simulation, which results in significantly greater concentrations of biogenic Volatile Organic Compounds (VOCs), which are highly sensitive to surface temperature. The largest increase in VOCs in the WRF-CMAQ simulation (not shown) occurs along the Gulf of Mexico and through the upper Midwest, where the increase in the monthly average VOC mixing ratios is typically greater than $20 \%$, with the concentrations in some areas more than doubling. The areas with large increases $(>20 \%)$ in VOC mixing ratios in the WRF-CMAQ simulation correspond to those areas where $\mathrm{O}_{3}$ mixing ratios were also much higher than in the MM5-CMAQ simulation. 


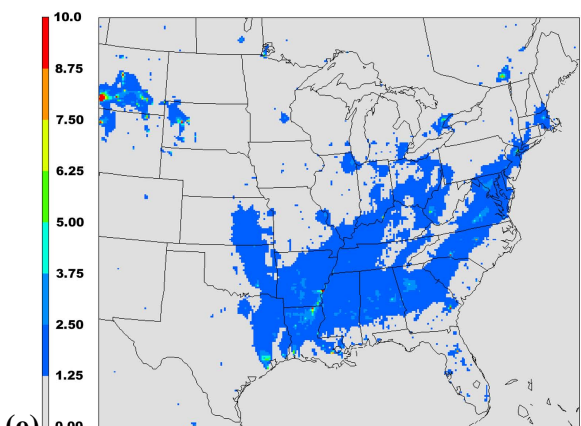

(e) ${ }^{0.00}$

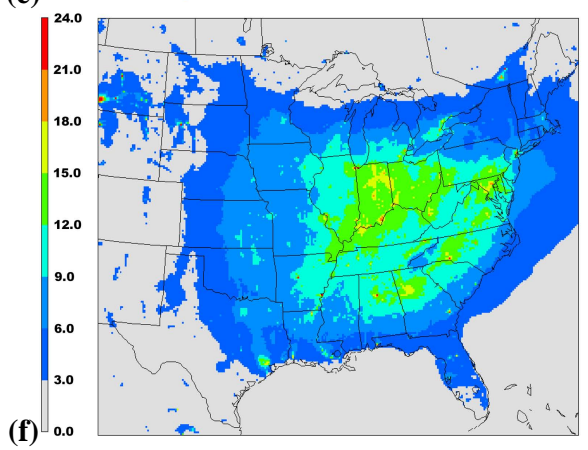

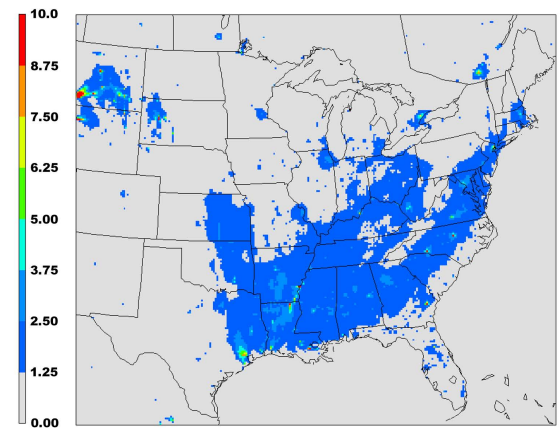

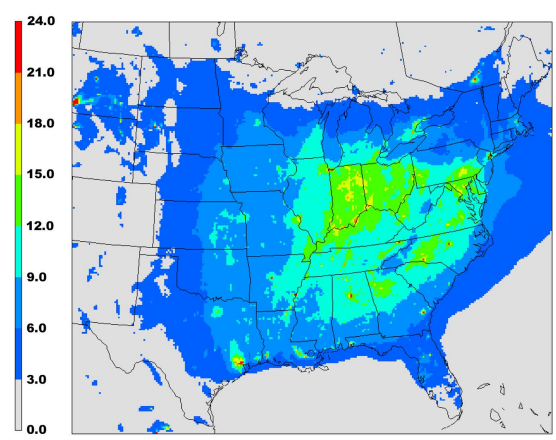

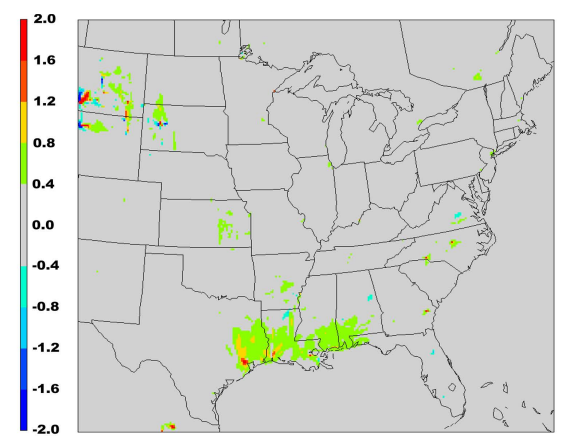

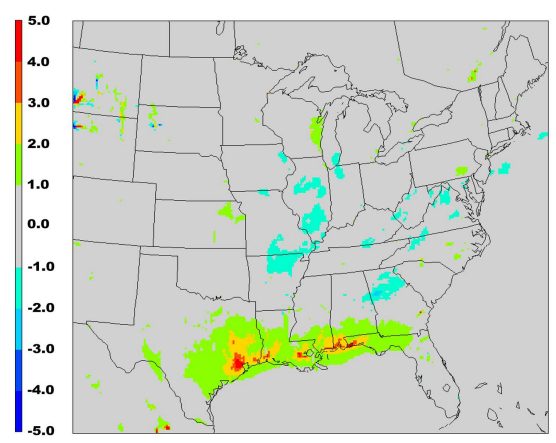

Fig. 6. Continued.

A third difference between the MM5-CMAQ and WRFCMAQ simulations that likely plays a role in the difference in the predicted $\mathrm{O}_{3}$ mixing ratios (and other species as well) is the differences in the calculation of the $u_{*}$ in each of the models, which was described previously in Sect. 4.1.3. The differences in the calculation of the $u_{*}$ result in higher concentrations of $\mathrm{NO}$ and $\mathrm{NO}_{2}\left(\mathrm{NO}_{\mathrm{x}}\right)$ in the WRF-CMAQ simulation, which is generally favorable for greater $\mathrm{O}_{3}$ production. The combination of increased VOC and $\mathrm{NO}_{\mathrm{x}}$ mixing ratios results in $\mathrm{O}_{3}$ mixing ratios that are considerably higher across a large portion of the domain in the WRF-CMAQ simulation. The increase in $\mathrm{O}_{3}$ may also be enhanced slightly along the Gulf of Mexico by a narrower and weaker seabreeze front that was observed in the WRF model simulation, which results in less mixing along the coast. While other differences no doubt exist between the two simulations, these differences were identified as the most important factors contributing to the higher predicted $\mathrm{O}_{3}$ mixing ratios in the WRF-CMAQ simulation.

As was done with January, an MM5 simulation was performed for August in which in the minimum value for $u_{*}$ in the MM5 code was changed from $1.0 \mathrm{~m} \mathrm{~s}^{-1}$ to $0.1 \mathrm{~m} \mathrm{~s}^{-1}$ to match the WRF model code for the calculation for $u_{*}$. The new MM5 simulation showed virtually no difference in the calculated values of $u_{*}$, which was also the case with the January simulation. The wind speeds in the WRF simulation in August tend to be lower than MM5 during the nighttime hours, indicated in Fig. 1d by the larger negative bias in wind speed, which may contribute to the lower values of $u_{*}$ in the
WRF model simulation. To test the impact that $u_{*}$ has on the CMAQ model predictions in August, an MM5-CMAQ simulation was performed for in which the $u_{*}$ and aerodynamic resistance values calculated by the WRF model were used instead of those from MM5. As expected, replacing the MM5 calculated $u_{*}$ values with those from the WRF simulation resulted in higher predicted mixing ratios of $\mathrm{O}_{3}$, with increases in $\mathrm{O}_{3}$ generally ranging from 1.0 to $2.0 \mathrm{ppb}$ over a large area (Fig. 9a). While differences in the $u_{*}$ values in the MM5 and WRF model simulations may contribute to some of the differences in the CMAQ model predictions, other differences between the meteorological models (e.g. differences in predicted cloud cover affecting photolysis) likely play a larger role.

\subsubsection{Fine particulate sulfate $\left(\mathrm{SO}_{4}^{2-}\right)$}

The predicted monthly average $\mathrm{SO}_{4}^{2-}$ for the two CMAQ simulations for August is shown in Fig. 5b. There are two well-defined areas with significant differences in the predicted $\mathrm{SO}_{4}^{2-}$ concentrations; one being the area surrounding the Ohio Valley, where $\mathrm{SO}_{4}^{2-}$ concentrations are lower in the WRF-CMAQ simulation and the other being the area along the Gulf of Mexico, where $\mathrm{SO}_{4}^{2-}$ concentrations are higher in the WRF-CMAQ simulation. The result of the differences in $\mathrm{SO}_{4}^{2-}$ predictions is higher bias and error in the WRF-CMAQ simulation, with the NMdnB 0.1-9.3\% higher and the MdnB $0.0-0.44 \mu \mathrm{g} \mathrm{m}^{-3}$ higher than the MM5-CMAQ simulation (Table 3). Figure $7 \mathrm{~b}$ shows the spatial distribution of the 


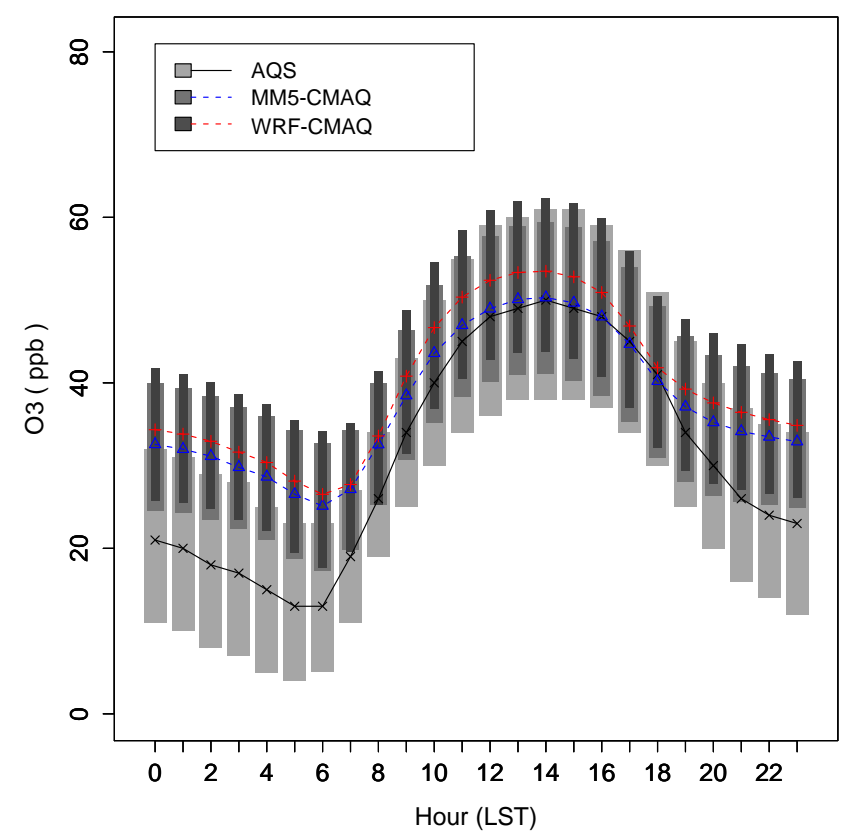

Fig. 7. Diurnal domain-wide average $\mathrm{O}_{3}$ for August 2006 for AQS observed (black solid crosses; light gray shading), MM5-CMAQ predicted (dashed blue triangles; medium gray shading) and WRFCMAQ predicted (dashed red plus signs; dark gray shading). The solid and dashed lines represent the average hourly $\mathrm{O}_{3}$ mixing ratios, while the shading represents the 25 th to 75 th percentiles.

difference in mean bias for $\mathrm{SO}_{4}^{2-}$ at the IMPROVE network, CSN and CASTNet sites. As expected, the largest increase in bias for the WRF-CMAQ simulation occurs in the Ohio Valley and adjacent regions, while there is a small improvement in the mean bias for sites along the Gulf of Mexico. The relatively dense collection of CASTNet sites in the Ohio Valley region results in the larger increase in bias and error for that network as compared to the CSN and IMPROVE networks (Table 3).

It was speculated that the lower predicted $\mathrm{SO}_{4}^{2-}$ concentrations in the Ohio Valley region in the WRF-CMAQ simulation were due to less aqueous-phase (in-cloud) production of $\mathrm{SO}_{4}^{2-}$, while the increase in $\mathrm{SO}_{4}^{2-}$ concentrations along the Gulf of Mexico were due to an increase in the gas-phase production of $\mathrm{SO}_{4}^{2-}$. To test this hypothesis, the sulfur tracking version of CMAQ, which provides the concentration of $\mathrm{SO}_{4}^{2-}$ from all the various sources (e.g. aqueous-phase, gasphase, direct emissions, etc.) within the CMAQ model was implemented for August. The results from the sulfur tracking version of CMAQ confirmed that the lower $\mathrm{SO}_{4}^{2-}$ concentrations in the Ohio Valley region were due to less aqueousphase $\mathrm{SO}_{4}^{2-}$ production, while the increase along the Gulf of Mexico was due to greater gas-phase $\mathrm{SO}_{4}^{2-}$ production and higher $\mathrm{OH}$ concentrations in that region (not shown).
The reduced aqueous-phase production of $\mathrm{SO}_{4}^{2-}$ concentrations in the WRF-CMAQ simulation were due to the CMAQ sub-grid cloud model diagnosing fewer nonprecipitating clouds than in the MM5-CMAQ simulation. A comparison of the precipitating and non-precipitating cloud fractions from CMAQ (available in the cloud diagnostic file) showed that the non-precipitating cloud fraction in the WRF-CMAQ model simulation was lower than that of the MM5-CMAQ simulation. Since non-precipitating clouds can be a significant source of $\mathrm{SO}_{4}^{2-}$ production in the atmosphere, it is likely that the lower $\mathrm{SO}_{4}^{2-}$ concentrations in the WRF-CMAQ simulation are due to this decrease in nonprecipitating clouds. The increase in $\mathrm{SO}_{4}^{2-}$ along the Gulf of Mexico may be related to an increase in photolysis reactions in that area which results in higher $\mathrm{OH}$ concentrations and an increase in the gas-phase production of $\mathrm{SO}_{4}^{2-}$ (which is also indicated by the higher $\mathrm{O}_{3}$ mixing ratios in that region).

\subsubsection{Fine particulate nitrate $\left(\mathrm{NO}_{3}^{-}\right)$and total nitrate $\left(\mathrm{TNO}_{3}\right)$}

Figure $5 \mathrm{c}$ and $\mathrm{d}$ shows the predicted monthly average $\mathrm{NO}_{3}^{-}$ and $\mathrm{TNO}_{3}$ for August for the two CMAQ model simulations. $\mathrm{NO}_{3}^{-}$and $\mathrm{TNO}_{3}$ are both higher in the WRF-CMAQ simulation, with the largest increases occurring in the region surrounding the Great Lakes and along the Gulf of Mexico. The higher predicted $\mathrm{NO}_{3}^{-}$and $\mathrm{TNO}_{3}$ concentrations in the WRFCMAQ simulation are possibly due to less dry deposition of $\mathrm{HNO}_{3}$ on average in the WRF-CMAQ simulation (a result of the difference in the calculation of $u_{*}$ between the two models). The higher concentrations of predicted $\mathrm{NO}_{3}^{-}$and $\mathrm{TNO}_{3}$ in the WRF-CMAQ simulation result in a decrease in the bias in $\mathrm{NO}_{3}^{-}$, which is largely underpredicted in both simulations, while the bias and error in $\mathrm{TNO}_{3}$ predictions increase substantially compared to the MM5-CMAQ simulation (Table 3).

As with $\mathrm{O}_{3}$, it was suspected that lower values of $u_{*}$ in the WRF model simulation were resulting in less dry deposition of $\mathrm{NO}_{\mathrm{x}}$ and $\mathrm{HNO}_{3}$, which results in higher concentrations of $\mathrm{TNO}_{3}$ in the WRF-CMAQ simulation. Results from the MM5-CMAQ simulation in which the $u_{*}$ and aerodynamic resistance from the WRF simulation were used instead of those from MM5 show significantly higher concentrations of $\mathrm{TNO}_{3}$ in some areas, which supports the hypothesis that differences in $u_{*}$ play at least some role in the differences in $\mathrm{TNO}_{3}$ predictions in August. Increases in the $\mathrm{TNO}_{3}$ in the modified MM5-CMAQ simulation (as compared to the original MM5-CMAQ simulation) generally ranged from between 0.20 to $0.80 \mu \mathrm{g} \mathrm{m}^{-3}$ (Fig. 9b), which would contribute significantly to the differences in $\mathrm{TNO}_{3}$ in some areas shown in Fig. 5d. While the differences in dry deposition of $\mathrm{NO}_{\mathrm{x}}$ and $\mathrm{HNO}_{3}$ contribute to differences in predicted $\mathrm{TNO}_{3}$ concentrations in some areas, other differences in the meteorological predictions are obviously important as well. 

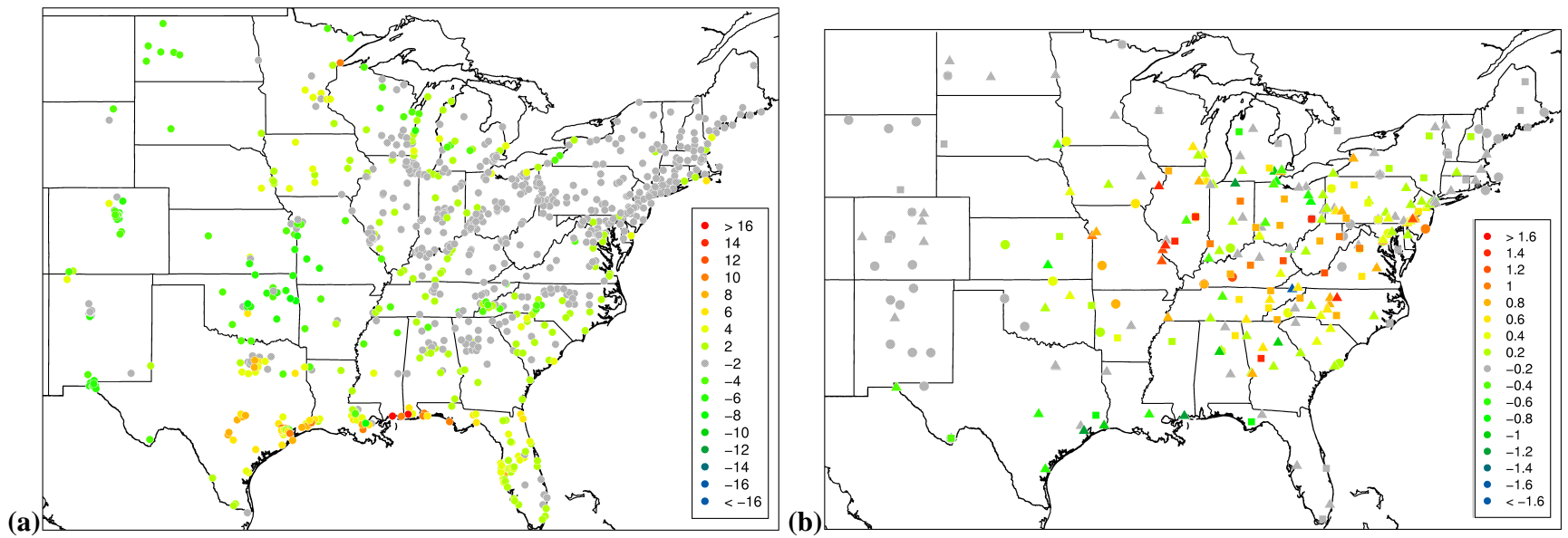

Fig. 8. Average difference in the mean bias between the MM5-CMAQ and WRF-CMAQ simulations for (a) maximum 8-h average $\mathrm{O}_{3}$ (ppb) at the AQS sites and (b) $\mathrm{SO}_{4}^{2-}\left(\mu \mathrm{g} \mathrm{m}^{-3}\right)$ at IMPROVE (circle), CSN (triangle) and CASTNet (square) for August 2006. Warmer shading represents higher bias in the WRF-CMAQ simulation; cooler shading represents lower bias in the WRF-CMAQ simulation; gray shading represents a difference in mean bias of less than $2 \mathrm{ppb}$ or $0.2 \mu \mathrm{g} \mathrm{m}^{-3}$ between the two simulations.
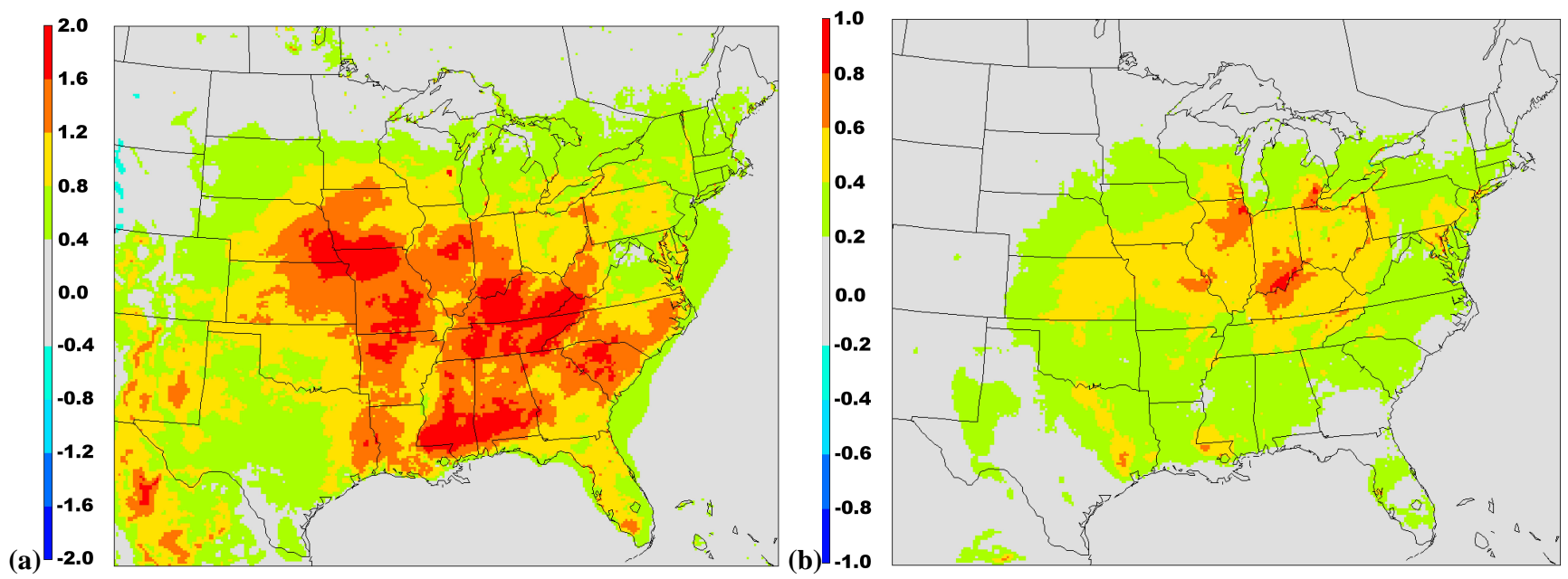

Fig. 9. Difference in monthly average (a) $\mathrm{O}_{3}$ mixing ratios (ppb) and (b) $\mathrm{TNO}_{3}\left(\mu \mathrm{g} \mathrm{m}^{-3}\right.$ ) between the MM5 simulation using $u_{*}$ values calculated by WRF and the original MM5 simulation.

\subsubsection{Total carbon (TC)}

The largest differences in monthly average TC between the two simulations are generally limited to two regions, one along the Gulf of Mexico and the other in the upper Midwest (Fig. 5e). TC is largely underpredicted in both simulations (Table 3), and that underprediction is slightly less in the WRF-CMAQ simulation, with the NMdnB 5.7-7.4\% lower and the MdnB 0.09-0.23 $\mu \mathrm{g} \mathrm{m}^{-3}$ lower than the MM5CMAQ simulation. Differences in the predicted TC concentrations between the two simulations are likely related to the same factors that result in the higher $\mathrm{O}_{3}, \mathrm{SO}_{4}^{2-}$ and $\mathrm{TNO}_{3}$ concentrations.

\subsubsection{Total fine particulate mass $\left(\mathbf{P M}_{2.5}\right)$}

Predictions of total $\mathrm{PM}_{2.5}$ mass are on average higher in the WRF-CMAQ simulation for August (Table 3), which results in a small improvement in the bias and error, as $\mathrm{PM}_{2.5}$ mass is underpredicted in both simulations. The NMdnB and MdnB decrease by $4.6-7.2 \%$ and $0.29-0.86 \mu \mathrm{g} \mathrm{m}^{-3}$, respectively, while the NMdnE and MdnE decrease by $3.4-4.1 \%$ and $0.26-0.41 \mu \mathrm{g} \mathrm{m}^{-3}$, respectively. The largest increase in $\mathrm{PM}_{2.5}$ mass in the WRF-CMAQ simulation occurs along the Gulf of Mexico, where the increases in $\mathrm{SO}_{4}^{2-}, \mathrm{TNO}_{3}$ and TC in that same region result in widespread monthly average differences in total $\mathrm{PM}_{2.5}$ mass of more than $1 \mu \mathrm{g} \mathrm{m}{ }^{-3}$, and in 


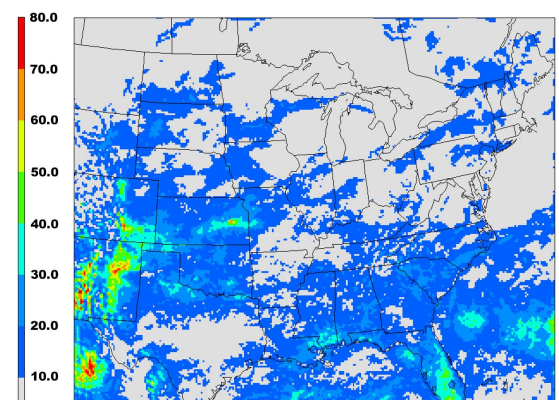

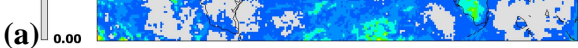

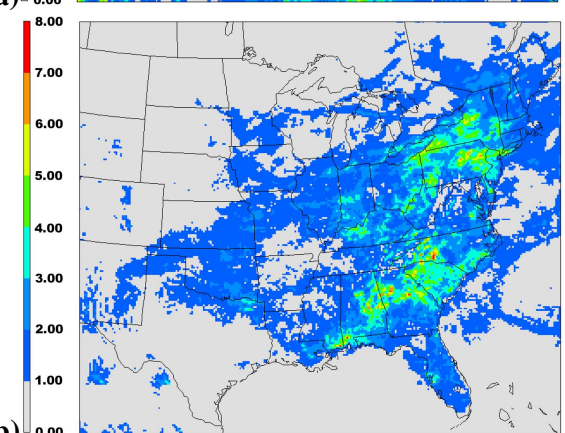

(b)

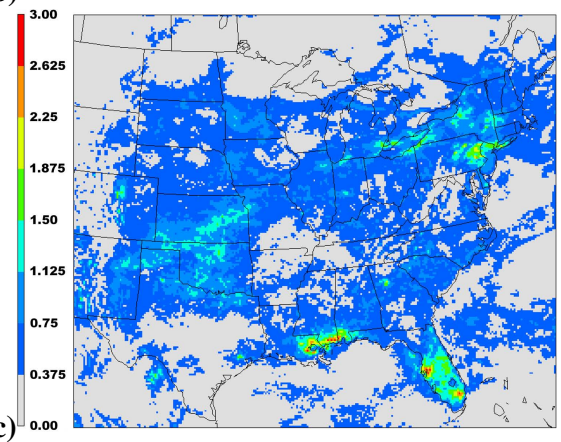

(c)

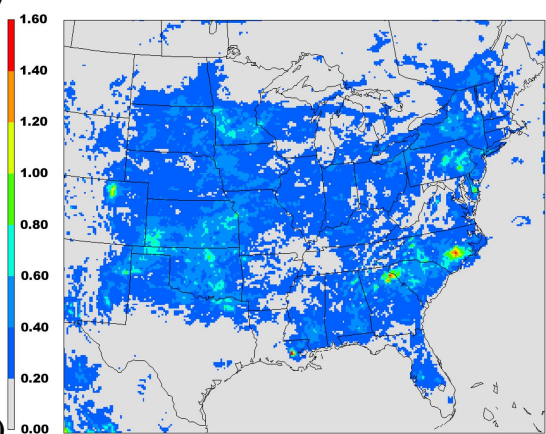

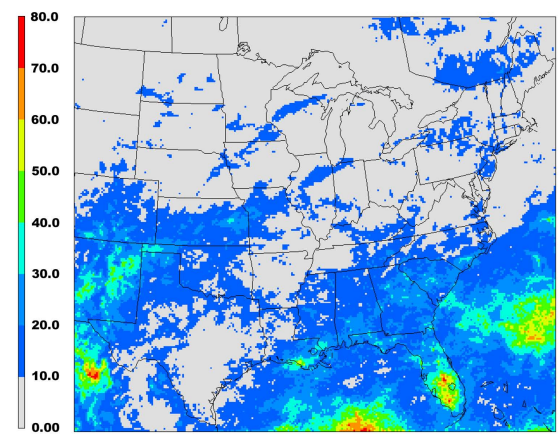
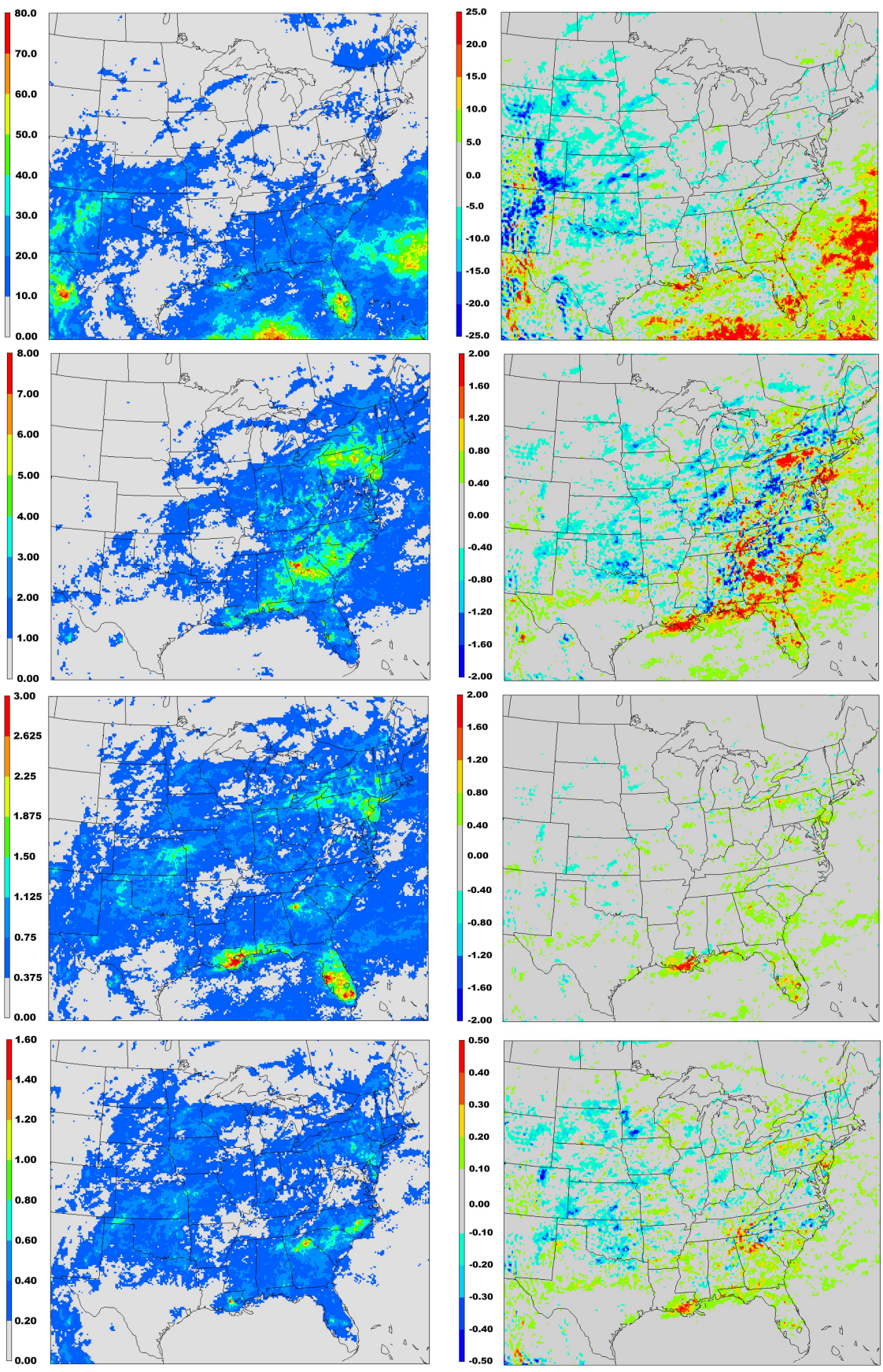

Fig. 10. Monthly average concentrations of MM5-CMAQ (left column), WRF-CMAQ (middle column) and WRF-CMAQ - MM5-CMAQ (right column) for (a) precipitation (cm), (b) $\mathrm{SO}_{4}^{2-}$ wet deposition $\left(\mathrm{kg} \mathrm{ha}^{-1}\right)$, (c) $\mathrm{NO}_{3}^{-}$wet deposition $\left(\mathrm{kg} \mathrm{ha}^{-1}\right)$ and (d) $\mathrm{NH}_{4}^{+}$wet deposition $\left(\mathrm{kg} \mathrm{ha}^{-1}\right)$ for August 2006.

some areas differences exceeding $5 \mu \mathrm{g} \mathrm{m}^{-3}$ (Fig. 5f). There are some isolated areas in the Ohio Valley and surrounding regions where the $\mathrm{PM}_{2.5}$ mass decreases by $1-2 \mu \mathrm{g} \mathrm{m}^{-3}$ in the WRF-CMAQ simulation. Differences in $\mathrm{PM}_{2.5}$ mass are due to the differences in the $\mathrm{PM}_{2.5}$ constituent species already discussed, along with differences in the prediction of the unspeciated mass.

\subsubsection{Wet deposition species}

The predicted monthly accumulated precipitation and $\mathrm{SO}_{4}^{2-}$, $\mathrm{NO}_{3}^{-}$and $\mathrm{NH}_{4}^{+}$wet deposition for August are shown in Fig. 8. There are widespread differences in the predicted precipitation between the two simulations (Fig. 8a). Much of the difference appears to be due to differences in the prediction 
of the convective precipitation from the two models. The WRF model tends to forecast more precipitation over the southeastern portion of the domain, including over the Atlantic Ocean, Gulf of Mexico and Florida and along the Gulf Coast states, while the MM5 model predicts greater precipitation over the Midwest. Both models overpredict precipitation on average, with the WRF model simulation having a smaller NMdnB and MdnB than the MM5 simulation (Table 3).

Differences in $\mathrm{SO}_{4}^{2-}$ wet deposition are widespread and mixed throughout much of the domain (Fig. 8b). Greater $\mathrm{SO}_{4}^{2-}$ wet deposition occurs over the Southeast and along the Gulf of Mexico in the WRF-CMAQ simulation, which correlates to regions where greater precipitation was observed as well, while there are areas in the Midwest with less $\mathrm{SO}_{4}^{2-}$ wet deposition in the WRF-CMAQ simulation, which correlate to areas where less precipitation was also predicted. There are, however, also large differences in $\mathrm{SO}_{4}^{2-}$ wet deposition in the Northeast, a region where large differences in precipitation were not observed. It is not immediately apparent what the cause of these differences is, and requires further investigation. Overall, the performance for $\mathrm{SO}_{4}^{2-}$ wet deposition at the NADP network sites is slightly better for the WRF-CMAQ simulation, with slightly less bias and error as compared to the MM5-CMAQ simulation (Table 3). The $\mathrm{NO}_{3}^{-}$and $\mathrm{NH}_{4}^{+}$wet deposition (Fig. 8c and d) show similar patterns to the $\mathrm{SO}_{4}^{2-}$ wet deposition, with higher deposition of those species in the Southeast and along the Gulf of Mexico in the WRF-CMAQ simulation. These increases in wet deposition are likely due to the combination of increases in aerosol concentrations of those species as well as greater predicted precipitation in those regions in the WRF model simulation. The overall statistical performance for $\mathrm{NO}_{3}^{-}$and $\mathrm{NH}_{4}^{+}$wet deposition is slightly better for the WRF-CMAQ simulation (Table 3).

\section{Summary}

Two sets of CMAQv4.7 simulations were performed for January and August 2006, with one set using the MM5 meteorology and the other set using WRF model meteorology. Predictions from the CMAQ model simulations were compared against observations from various networks and the performance for each set of simulations was assessed and compared against the other set. For January, performance differences in the predicted $\mathrm{O}_{3}$ mixing ratios from each simulation appear to be the result of differences in the calculation of the vegetation fraction between the two simulations, which ultimately affects the amount of $\mathrm{O}_{3}$ dry deposition that takes place in each simulation. Higher predicted concentrations of $\mathrm{SO}_{4}^{2-}$ in January in the WRF-CMAQ simulation are likely related to a combination of more predicted cloud cover, which results in an increase in the amount of aqueous-phase (in-cloud) $\mathrm{SO}_{4}^{2-}$ produced, and less $\mathrm{SO}_{4}^{2-}$ wet deposition as compared to the MM5-CMAQ simulation. Predictions of $\mathrm{NO}_{3}^{-}$and $\mathrm{TNO}_{3}$ were also higher in the WRF-CMAQ simulation, likely due to lower predicted wind speeds and PBL heights in the WRF simulation, which result in less mixing and hence greater surface concentrations. A likely secondary contributor to the differences in $\mathrm{TNO}_{3}$ concentrations in the January are differences in the calculated $u_{*}$ values in the MM5 and WRF model simulations, where smaller $u_{*}$ values calculated in the WRF model simulations result in less dry deposition of $\mathrm{HNO}_{3}$ (and hence greater ambient concentrations) in the WRF-CMAQ simulation.

For August, the WRF-CMAQ simulation generally underperformed compared to the MM5-CMAQ simulation. The bias in $\mathrm{O}_{3}$ mixing ratios was higher in the WRF-CMAQ simulation, with the largest increases in bias occurring in the southeast United States, particularly in Florida, along the Gulf of Mexico and in Texas. The increase in predicted $\mathrm{O}_{3}$ mixing ratios in the WRF-CMAQ simulation appears to be most directly related to greater predicted surface SR (due to fewer predicted clouds) in the WRF-CMAQ simulation, which results in higher surface temperatures and an increase in the mixing ratios of surface biogenic VOCs. Additionally, the smaller predicted CFRAC in the WRF-CMAQ simulation results in an increase in the amount of $\mathrm{O}_{3}$ photolysis taking place. Less dry deposition of $\mathrm{NO}_{\mathrm{x}}$ due to lower $u_{*}$ values also appears to contribute to the higher $\mathrm{O}_{3}$ mixing ratios in the WRF-CMAQ simulation.

Predicted concentrations of $\mathrm{SO}_{4}^{2-}$, which were already underpredicted in both simulations, were lower in the WRFCMAQ simulation in the Ohio Valley region, but higher along the Gulf coast states. The decrease in predicted $\mathrm{SO}_{4}^{2-}$ concentrations in the WRF-CMAQ simulation is likely related to fewer predicted non-precipitating clouds in the WRF-CMAQ simulation, which results in less aqueousphase production of $\mathrm{SO}_{4}^{2-}$ in the Midwest and Ohio Valley, while the increase along the Gulf of Mexico is due to greater gas-phase production of $\mathrm{SO}_{4}^{2-}$. Predicted concentrations of $\mathrm{NO}_{3}^{-}$and $\mathrm{TNO}_{3}$ were higher in the WRF-CMAQ simulation, which is thought to be a result of increased concentrations of $\mathrm{NO}_{x}$ and $\mathrm{HNO}_{3}$, due in part to less dry deposition of those species in some areas (due to differences in the $u_{*}$ calculation) and to an increase in $\mathrm{NO}_{3}^{-}$replacement in response to lower predicted $\mathrm{SO}_{4}^{2-}$ concentrations. Other differences in the meteorological predictions, such as cloud cover, PBL heights and handling of the land-sea interface along the Gulf of Mexico, likely play a large role in the differences in $\mathrm{NO}_{3}^{-}$ and $\mathrm{TNO}_{3}$ as well.

The most significant differences in the meteorological predictions are related to the predictions of wind speed, PBL height, $u_{*}$, water vapor and the predicted cloud cover, all of which appear to contribute to differences in the CMAQ model predictions. However, it should be noted that the comparison presented here is limited to two months from a single year. Additional comparisons during other time periods 
would be useful for quantifying the robustness of the results presented here. This could be accomplished by extending the comparison to an annual or multi-annual simulation, which would capture differences under many different meteorological regimes. It should also be noted that while the comparison presented here uses configurations of the meteorological models that are typical of those used for air quality applications, many different configurations of the MM5 and WRF models are possible, and comparisons of CMAQ model predictions using different configurations of the meteorological models may lead to results that are different than those presented here. Finally, the results presented here are also limited geographically to the eastern United States. An analysis of the performance for the western United States would be beneficial, since the meteorology and air quality conditions in the western United States can be quite different from those of the eastern United States.

Acknowledgements. The authors would like to thank Lara Reynolds of Computer Sciences Corporation for her help developing and processing the MM5 simulations used in this study, and to Prakash Bhave for providing the section describing the computation of $\mathrm{PM}_{2.5}$ mass from the CMAQ model.

Disclaimer. The United States Environmental Protection Agency through its Office of Research and Development funded and managed the research described here. It has been subjected to Agency review and approved for publication.

Edited by: W. Hazeleger

\section{References}

Appel, K. W., Bhave, P. V., Gilliland, A. B., Sarwar, G., and Roselle, S. J.: Evaluation of the Community Multiscale Air Quality (CMAQ) model version 4.5: Sensitivities impacting model performance; Part II - particulate matter, Atmos. Environ., 42, 6057-6066, 2008.

Appel, K. W., Gilliland, A. B., Sarwar, G., and Gilliam, R. C.: Evaluation of the Community Multiscale Air Quality (CMAQ) model version 4.5: Sensitivities impacting model performance: Part I Ozone, Atmos. Environ., 41, 9603-9615, 2007.

Appel, K. W. and Gilliam, R. C.: Overview of the Atmospheric Model Evaluation Tool (AMET), 7th Annual CMAS Conference, Chapel Hill, NC, http://www.cmascenter.org/conference/ 2008/agenda.cfm, 6-8 October 2008.

Byun, D. W. and Schere, K. L.: Review of the governing equations, computational algorithms, and other components of the Models3 Community Multiscale Air Quality (CMAQ) modeling system, Appl. Mech. Rev., 55, 51-77, 2006.

Carlton, A. M. G., Bhave, P. V., Napelenok, S. L., Pinder, R. W., Sarwar, G., Pouliot, G. A., Edney, E. O., and Houyoux, M.: Improved Treatment of Secondary Organic Aerosols in CMAQ, Environ. Sci. Technol., submitted, 2010.

de Meij, A., Gzella, A., Cuvelier, C., Thunis, P., Bessagnet, B., Vinuesa, J. F., Menut, L., and Kelder, H. M.: The impact of MM5 and WRF meteorology over complex terrain on CHIMERE model calculations, Atmos. Chem. Phys., 9, 6611-6632, 2009, http://www.atmos-chem-phys.net/9/6611/2009/.

Deng, A., Stauffer, D. R., Dudhia, J., Hunter, G. K., and Bruyere, C.: WRF-ARW analysis nudging update and future development plan. 9th Annual WRF Users' Workshop, Boulder, CO, http://www.mmm.ucar.edu/wrf/users/workshops/ WS2008/abstracts/1-06.pdf, 23-27 June 2008.

Dudhia, J.: Numerical study of convection observed during the winter monsoon experiment using a mesoscale two-dimensional model, J. Atmos. Sci., 46, 3077-3107, 1989.

ENVIRON: User's Guide to the Comprehensive Air Quality Model with Extensions (CAMx) Version 5.10, ENVIRON International Corporation, 773 San Marin Drive, Suite 2115 Novato, California 94998, available at http://www.camx.com/files/ CAMxUserGuide_v5.10.pdf, 2009.

Foley, K. M., Roselle, S. J., Appel, K. W., Bhave, P. V., Pleim, J. E., Otte, T. L., Mathur, R., Sarwar, G., Young, J. O., Gilliam, R. C., Nolte, C. G., Kelly, J. T., Gilliland, A. B., and Bash, J. O.: Incremental testing of the community multiscale air quality (CMAQ) modeling system version 4.7, Geosci. Model Dev. Discuss., 2, 1245-1297, 2009.

Fulton, R. A., Breidenbach, J. P., Seo, D. J., Miller, D. A., and O'Bannon, T.: The WSR-88D rainfall algorithm, Wea. Forecasting, 13, 377-395, 1998.

Gilliam, R. C. and Pleim, J. E.: Performance assessment of new land-surface and planetary boundary layer physics in the WRFARW, J. Appl. Meteor. Clim., doi:10.1175/2009JAMC2126.1, 2010.

Grell, G. A., Dudhia, A. J., and Stauffer, D. R.: A description of the Fifth-Generation PennState/NCAR Mesoscale Model (MM5). NCAR Technical Note NCAR/TN-398+STR. Available at http://www.mmm.ucar.edu/mm5/doc1.html, 1994.

Jiang, W., Smyth, S., Giroux, E., Roth, H., and Yin, D.: Differences between CMAQ fine mode particle and PM2.5 concentrations and their impact on model performance evaluation in the lower Fraser valley, Atmos. Environ., 40, 4973-4985, 2006.

Kain, J. S.: The Kain-Fritsch convective parameterization: An update, J. Appl. Meteor., 43, 170-181, 2004.

Mlawer, E. J., Taubman, S. J., Brown, P. D., Iacono, M. J., and Clough, S. A.: Radiative transfer for inhomogeneous atmosphere: RRTM, a validated correlated-k model for the long-wave, J. Geophys. Res., 102(D14), 16663-16682, 1997.

Otte, T. L.: The impact of nudging in the meteorological model for retrospective air quality simulations. Part I: Evaluation against national observations networks, J. Appl. Meteor. Clim., 47, 1853-1867, 2008.

Otte, T. L., Pouliot, G., Pleim, J. E., Young, J. O., Schere, K. L., Wong, D. C., Lee, P. C. S., Tsidulko, M., McQueen, J. T., Davidson, P., Mathur, R., Chuang, H. Y., DiMego, G., and Seaman, N. L.: Linking the Eta model with the Community Multiscale Air Quality (CMAQ) modeling system to build a national air quality forecasting system, Wea. Forecasting, 20, 367-384, 2005.

Pleim, J. E. and Xiu, A.: Development and testing of a surface flux and planetary boundary layer model for application in mesoscale models, J. Appl. Meteor., 34, 16-32, 1995.

Pleim, J. E. and Xiu, A.: Development of a Land-surface Model. Part II: Data Assimilation, J. Appl. Meteor., 42, 1811-1822, 2003.

Pleim, J. E.: A combined local and nonlocal closure model for the 
atmospheric boundary layer. Part I: model description and testing, J. Appl. Meteor. Clim., 46, 1383-1395, 2007a.

Pleim, J. E.: A combined local and nonlocal closure model for the atmospheric boundary layer. Part II: application and evaluation in a mesoscale meteorological model, J. Appl. Meteor. Clim., 46, 1396-1409, 2007b.

Reisner, J., Rasmussen, R. M., and Bruintjes, R. T.: Explicit forecasting of supercooled liquid water in winter storms using the MM5 mesoscale model, Q. J. Roy. Meteorol. Soc., 124, 10711107, 1998.

Seo, D. J.: Real-time estimation of rainfall fields using rain gauge data under fractional coverage conditions, J. Hydrol., 208, 2536, 1998a.

Seo, D. J.: Real-time estimation of rainfall fields using radar rainfall and rain gauge data, J. Hydrol., 208, 37-52, 1998 b.

Skamarock, W. C., Klemp, J. B., Dudhia, J., Gill, D. O., Barker, D. M., Duda, M. G., Huang, X-Y, Wang, W., and Powers, J. G.: A description of the advanced research WRF version 3. NCAR Tech Note NCAR/TN 475 STR, 125 pp, available from UCAR Communications, P.O. Box 3000, Boulder, CO 80307, 2008.
Smyth, S. C., Yin, D., Roth, H., Jiang, W., Moran, M. D., and Crevier, L. P.: The impact of GEM and MM5 modeled meteorological conditions on CMAQ air quality modeling results in Eastern Canada and the Northeastern United States, J. Appl. Meteor. Clim., 45, 1525-1541, 2006.

Stauffer, D. R., Seaman, N. L., and Binkowski, F. S.: Use of fourdimensional data assimilation in a limited-area mesoscale model. Part II: Effects of data assimilation within the planetary boundary layer, Mon. Weather Rev., 119, 734-754, 1991.

Thompson, G., Rasmussen, R. M., and Manning, K.: Explicit forecasts of winter precipitation using an improved bulk microphysics scheme. Part I: Description and sensitivity analysis, Mon. Weather Rev., 132, 519-542, 2004.

Xiu, A. and Pleim, J. E.: Development of a land-surface model. Part I: application in a mesoscale meteorological model, J. Appl. Meteor., 40, 192-209, 2001.

Yarwood, G., Roa, S., Yocke, M., and Whitten, G.: Updates to the carbon bond chemical mechanism: CBo5. Final report to the US EPA, RT-0400675, available at http://www.camx.com, 2005. 